University of Rhode Island

DigitalCommons@URI

Open Access Master's Theses

1982

\title{
LOST IN THE IRON TRIANGLE: PUBLIC POLICY MAKING IN RHODE ISLAND
}

Kenneth Daniel Haupt

University of Rhode Island

Follow this and additional works at: https://digitalcommons.uri.edu/theses

\section{Recommended Citation}

Haupt, Kenneth Daniel, "LOST IN THE IRON TRIANGLE: PUBLIC POLICY MAKING IN RHODE ISLAND" (1982). Open Access Master's Theses. Paper 512.

https://digitalcommons.uri.edu/theses/512

This Thesis is brought to you for free and open access by DigitalCommons@URI. It has been accepted for inclusion in Open Access Master's Theses by an authorized administrator of DigitalCommons@URI. For more information, please contact digitalcommons-group@uri.edu. 


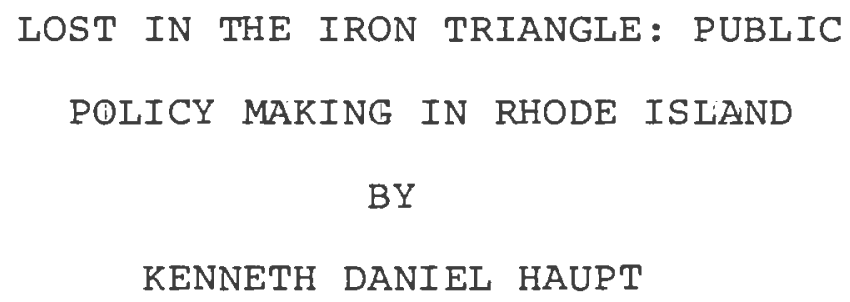

A PROJECT SUBMITTED IN PARTIAL FULFILLMENT OF THE REQUIREMENTS FOR THE DEGREE OF MASTER OF COMMUNITY PLANNING

\section{UNIVERSITY OF RHODE ISLAND}

1932 
MASTER OF COMMUNITY PLANNING

RESEARCH PROJECT

$O F$

KENNETH D. HAUPT

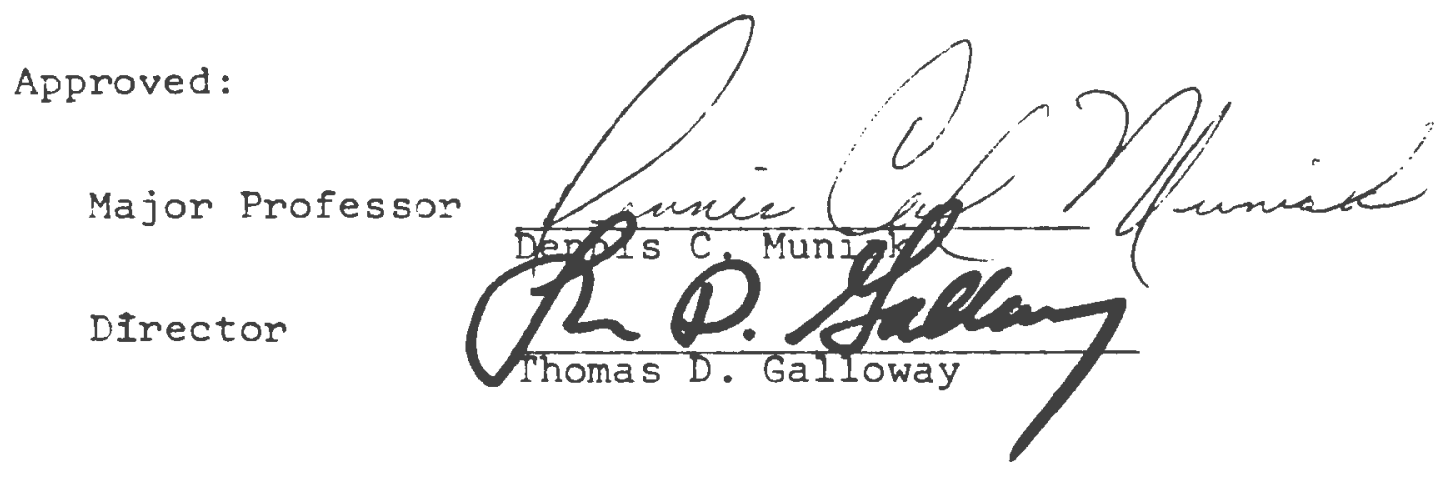




\section{Acknowledgements}

Many people helped me to make this project possible. There are too many to name. However, some contributions stand out.

First, my deepest appreciation goes to the people who took time out of their busy workdays to talk to me. Everyone who I aksed for an interview readily granted one. Their candor was invaluable.

Second, many thanks go to Ezra Schneider. He was always willing to sit down and talk about various aspects of the water pollution program. His information and insights were invaluable to me.

Finally, I must acknowledge my debt to my major professor, Dr. Dennis Muniak. His classes gave me the framework I needed to write this paper. He was always willing to sit down and talk about this project. He helped clarify my thinking and bring my ideas into sharper focus. He shares a large measure of whatever merit this paper has. The responsibility for the shortcomings is, of course, my own. 


\section{Preface}

This paper grew out of an internship I did at the firm of Charles J. Krasnoff and Associates from the summer of 1980 to spring 1982. As a participant as well as an observer a lot of information came my way that was useful to this paper. A lot of it was verbal.

To research this paper I relied upon personal experience, various documentary sources, the reports of the Providence Journal-Bulletin newspapers and personal interviews.

In the text there are many instances where a statement or sentiment is attributed to an individual without a footnote. In these instances it represents a statement or an event that I witnessed or was made to me. Standard historiographical practice does not require footnoting in such circumstances.

Everything outside my personal experience and knowledge has been footnoted, with several exceptions. These are instances when information was given to me and it seemed prueent to protect my informant. (the prime instance is my explanation, as given to me by a well informed source, of the real background to the Bucci incident) I only resorted to this device rarely. Even if the events recounted are not accepted as true, it would not detract from the main points made in the report. 


\section{INIRODUCTION}

This paper grew out of an internship I did with the City of Providence it Water Pollution Abatement Program Public Participation Program. I worked with the staff of Charles J. Krasnoff and Associates, who had the contract to run the program. I did not expect to find a master's project when I started ( Summer 1980). After a few months I realized that there was an interesting story right under my nose. I resolved to write about it.

Rhode Island is a small state, perhaps the closest thing in North America to an ancient city state. The area of the state is campact; most of the state's population lives in the metropolitan Providence area.

Because the state is so small everything is handy. " Everybody knows everybody or knows sameone who does.", marveled one person who moved here. The bureaucracy is small and concentrated. For this reason it is supposed by some that Rhode Island is the perfect, small laboratory to test innovation in govermment. Everything happens on a small scale; for that reason it should be easy for the elected politicians to concieve an idea and get it implemented.

I propose to turn this idea upside down. Rhode Island's true value is to discover why things don't work. It is so small its bureaucracy is comparitively easy to observe. Rhode Island public figures are, in the experience of this writer, fairly accessible. ( no one I approched for an interview turned me down) What makes a bold new program, with a lot of high powered support go wrong? 
In 1982 this is not a new area of study, though most of players of real life implementation games have not given it much thought. This is a pity, for in the case of the prolonged effort to transfer the City of Providence's sewage treatment system to a state chartered regional agency mistakes were made which, as always, had to be paid for. It seems to be an immutable rule of organizational behavior that a shortcut taken some place has to be paid for in same other place. This was certainly true in Providence.

III

The goal of this paper is modest. There are two issues: (1)Could, the snarl over transferring the plant have been avoided? (2) Will the Bay Cammission effect substantial improvement for the large amount of money people of Rhode Island have invested in the Providence system? The first issue will be discussed in a chapter called"conclusive conclusions", the second a chapter called " Inconclusive Conclusions."

Toward the first end events since 1975 will be chronicled and analyzed. Just why has progress : toward the state takeover been so slow? As of April 1982 the Bay Commission has been operating for a year and a half, hiring staff. and spending money, with no idea as to when it will actually take over the Field's Point treatment plant.

The paper will show how the critics of the slow pace of progress should not be surprised. This study will illustrate that it was efforts to rush to a quick (or so it seemed), politically safe solution to a "manufactured" crisis which created many problems in the first place. 

The city government may have been a major part of the problem; it was not treated as a papt of the solution. It was simply shoved aside while a state appointed task force worked toward a solution.

The Cianci Administration has undoubtedly slowed things up considerably. Should this come as a shock? From the very beginning city officials have felt slighted. Mayor Cianci was not consulted before the Govemor intervened. Critics of the city goverrment refuse to give the Cianci Administration any credit for the things that have been accomplished, such as getting the plant running more or less adequately. The city's orneriness was occassionally justified, sometimes understandable, but never less. than human. In short, Mayor Cianci and his men, treated shabbily (or at least they thought so) and angry about it, reacted in a way that would surprise no one who has read The Prinoe. Small injuries are the worst to inflict; they inspire a desire for revenge that can be carried out. Sooner or later the City had to be dealt with. When it came time to sit down an work things out Vincent Cianci, like Shylock, demanded his pound of flesh. No matter the demand was ultimately self defeating. It didn't stop Shylock and it didn't stop Vinoent A. Cianci, Jr.

The second part of this report will consider the potential usefulness of the Bay Commission. Since the level of success of the Bay Commission will not be known for some years it is to some extent an unanswerable question. However, the Bay Commission setup has its critics, most notably Mayor Cianci's former top aide, Ronald Glantz. The pros and cons of the Cormisrion will be discussed. Some sort of new admini- 
strative and financial arrangements were needed. Was this the best way to go? Was this a price the people of Rhode Island wanted to pay? Would there be a tremendous improvement to justify spending all that money? These questions will be analyzed from the gerspective of a professional planner.

\section{IV}

But why a paper about Providence's sewers? Most of the people I explained this project to thought it a boring, unattractive proposition. Of course, they are wrong.

In Rhode Island almost all the players and fringe characters in this game are located in and around downtown Providence. The key people usually attended the monthly meetings of City's Citizen Advisory Comittee. .

These meetings, plus regular contact with many players, gave this observer a unique opportunity to keep the entire field of play in sight and in focus. It made for a project that was both interesting to do and manageable. (for example: Save the Bay is located across the street fram the State House; down the street, in dcintown Providenoe, is City Hall; behind City Hall are the offices of the Bay Commission; almost next door are the offices of Charles J. Krasnoff and Associates; two or three blocks away are the offices of Louise Durfee and Mary Kilmarx; nearby are the offices of the Rhode Island Public Expenditure Council)

The iron triangle is one of the most useful concepts of public ad- 
ministration theory. Briefly, it is the configuration of interest groups, executive agencies and legislative committees that surrouni and dominate a policy area. They may fight each other at times, but will unite to protect "their" turf against outsiders. Iron triangles are established with ease; once in place, however, they are close to unbreakable. There are a few dozen decision makers, both mighty and moek, who constitute the perimter of the Providence iron triangle. Within the triangle the goal is to dominate the present and shape the future. In the case of Providence sewage treatment such critical questions as raising revenue, hiring the proper staff and deciding just how the Bay Commission's $\$ 87$ million bond issue is spent are issues of great interest to all.

There are some in the triangle who are prepared to spend (or rather, demand there be spent) a quarter billion dollars of state money to rebuild the Providence sewage treatment system. Others in the trianglewould hotly disprute this. It is a tremendous amount of money to raise, especially for Rhode Island. This sort of interplay goes on all the time in the Providence iron triangle. Enormously expensive issues are being worked out. All of this goes on in almost total obscurity. Why?

Sporting analogies are a tired device, but this writer will attempt one. This struggle is like a three sided football game where the object of the matci is not to score points, but to hold onto the ball- to move it where you please. With luck the side with the ball can per- 
suade the other sides to go along. This, from the spectator's viewpoint, makes for a very dull game indeed. With no scoreboard (since there are no points scored as the spectator understands them) and no clock it is dif ficult to understand who is winning. The game never really ends.

This is why there is so little news from the iron triangle. The press is still very attached to the "big ball game" approch when reporting political events. Who's ahead? Who's going to win? Who's on the way out? What does the latest poll say? The news media seems incapable of doing serious sustained research or presenting stories free of moralising. How much better to report on the petty chiseling rife in every buneaucracy rather than the more difficult story of whether the city needs all the expensive sewage treatment hardware. some would have it buy ?

The title of this project is Iost in the Iron Triangle. The iron triangle has already been defined. What gets lost is the ostensible goal of all parties: c cleaner Nurragarsett Bay, with increased opportunities for public recreaition and econamic explojtation. A year and a half in the Providence Water Pollution Program convinoed me this end is often far from some key actors: minds; the struggle for influence and power often overshadows all.

This is not to attack the sincerity of the participants. All want cleaner water; however, they want it on their terms. Some may think this cynical. That cannot be helped. The reader will decide whether miny analysis is backed by the evidence. 


\section{A Brief Description of the Bay}

The Act creating the Narragansett Bay Water Quality Management District Commission declares in the "findings" section that " Narragansett Bay may be the greatest natural resource of the State..." ${ }^{1}$ This is hardly an exageration, though it has become something of a local cliche.

When the last glacier receded 18,000 years $a^{2} 0^{2}$ it left behind a body of water that was bo'th scenic and rich. The "bottam community" is (or has been) rich in shell fish. The richest beds are in the upper Bay are either totally or almost totally inaccessible to fisherm men due to pollution. Pollution of the upper Bay and overfishing have caused quahog yields to fall from five million lbs. a year in 1955 to two million lbs. in $1978 .^{3}$

Fin fish are still abundant in the Bay. One recent University of Rhode Island publication describes aş, a "valuable feeding and spawning ground for many species. Its high primary productivity and rich benefits provide abundant and diverse food." 4 But things have been better.

In Colonial times lobsters were literally there for the picking. Large quantities of fish could be caught with a humble hook and liise anywhere. ${ }^{5}$ Improvements in fish catching technology increased yields. This drove fish away from the shore into deeper waters. ${ }^{6}$

The situation became so serious some forms of fishing, such as traps were prohibited. Trawlers $3 l s o$ contributed to the decline. ${ }^{7}$ Oysters 
and scallops, once"abundant" in the Bay, have totally disappeared. 8 In the 1980's the quahog industry is descibed as"severely threatened" by the encroachment of pollution southward. 9 (In 1979 the "conditional area" of the upper Bay was closed indefinitely. 9 It was only reopened on a limited basis in 1981)

The Bay has been a prime state recreation area sinoe the mid 19th century. Rocky Point, in Warwick, is the sole survivor of the amusement parks that once dotted the Bay. At the end of the last century Newport was famed as the summer playpen of "the 400". Narragansett and its Pier were also nationally renowned. 10

In our time the 40 year economic boom brought about by the second World War has led to irıcreased demands on the Bay. Many people now use the Bay for recreational boating. This increased recreational use of the Bay's waters certainly helped to pass the huge sewer bond issue in 1980.

Just how much of a menace'to the Bay is pollution. No one knows for sure. As the above mentioned URI report stated " A great many people are concerned about the pollution of the Bay, but when one digs into the nature and significance of the pollution problem, the finm conclusions that can be drawn become dissatisfyingly few ." Il

Present standards say most of the Bay is not polluted. Pollution is confined to the upper Bay. The problem there is described as"severe". 12 The Providence sewage treatment plant at Field's Point has been a major contibutor to the problem, but is not by any means the only offender. Every expert this writer consulted recognizes that we still do not know a great deal about what precisely pollutes the Bay. 
Growth of Providence and Pollution Problems Before 1900

Roger Williams, expelled from Massachusetts, landed in what is now Rhode Island in 1636. (the exact site is near Gano Street, on Providence's East Side) 1 The town of Providence was established and enjoyed modest prosperity. For many years the small town confined itself to the heights on the eastern side of the Great Salt Cove (now filled in) and the Providence River. Not until will into the 18th century did white people take root on the other side of the River. ${ }^{2}$

Until the Revolution Newport was the premier city of Rhode Island. Two things changed that: the British occupation, which devastated Newport, and industrialization. Providence took up the slack when war put Newport out of the trading picture. Providence's natural geograph: *lots of rivers) made it a natural industrial hub

The rivers and a fine harbor also made the town a natural industrial hub.. The rivers attracted the mills. The mills attracted the brand new steamships. With a strong base economy in place, what we would call the service sector moved in. The picture was completed when the first railroads were built from Providence to Boston in the 1830's. ${ }^{3}$ This meant the former backwater enjoyed (and suffered) fantastic population growth. From 1820 to 1860 the population of Providence grew $1,0008 !^{4}$ ( the state as a whole grew a comparitively piddling 154\% 5 By 1860 Providence had a population density of 7,560 per square mile. The entire state average was 223 p.s.m.. 6

The impact on the city was predictable. It quite literally stank. 7 Dr. Edwin Snow, the City's first Superintendent of Health, in his 
first year on the job (1857) depicts a city that was gag ging on its own excrement. ${ }^{8} \mathrm{Dr}$. Snow's knowledge of the causes of disease was typical for his time-limited. But he had made the crucial connection between disease and poor sanitation. 9 In 1857 he proposed " the commencement of a general system of sewers constructed on true scientific principles; and the earliest abolition and prohibition of cesspools." 10

By this time Rhode Island was the most industrialized state in the Union. ${ }^{11}$ But no sewers were built, much to the detriment of public health. Dr. Snow believed water pollution was a major cause of the cholera epidemics of 1832,1849 and 1854.12 His annual reports attest that for the average citizen Providence was not a nice place to live.

Something had to be done before the situation became dangerous. It was. In the early 1880's the City sent its engineer, Samuel Grey, to study European methods of sewage treatment. That same year (1881) Mr. Grey prodiced his report and a plan to sewer the entire city. It was a comprehensive effort, ${ }^{13}$ Grey recommened the treatment plant be built on a stretch of land overlooking deep water. It was well outside the settled areas and had been thought of as a potential resort: Field's Point. 14

By the late $80^{\prime}$ 's and early $90^{\prime}$ s work on the system was going at a fast clip. (as part of the city's sanitation effort the last of the Cove was filled in. By the early 1890 's it was regarded as an open sewer. It is now the site of Union Station and a parking lot) *

* There is a shelf in Brown University's Rockefeller Library that contains nothing but documents relating to the ongoing sewer project. It speaks volumes of an optimistic city on the move. 
Yet all was not well. The new century opened and the spanking new treatment plant commenced operations. It was regarded as one of the finest collections of machinery money could buy. ${ }^{15}$ state of the art we would say. The plant was operationg yet pollution was still terrible. Mayor Daniel Granger, in his inaugural address of January 6 , 1902 said, "The works at Field's Point are operating and everything within the power of the city is done to prevent the pollution of the River and the harbor within city limits. It is however, a matter of much regret, that although the city has expended millions of dollars to this end, yet she is obliged to suffer from the defilment of the woonosquatucket and Moshassuck Rivers beyond her borders." 16

One objective had been accomplished; human waste and some industrial waste was now disposed of via a treatment plant. Life on land was safer, The water was as bad as ever and was to stay so for a long time. 
Events to the Mid 1970s

By 1914 the Field's Point Plant was already considered in adequate. ${ }^{1} \mathrm{~A}$ pattern developed that was to be repeated for decades. There would be some unhappiness about the state of the city's waters, usually highlighted in the press. A bill would be filed. In 1919, for instance, a bill was introduced which would have established a metropolitan sewer board. It was never acted upon. ${ }^{2}$

Some unsuccessful efforts got farther then others. In 1933 the General Assembly created the Metropolitan Sewage Commission. This was a study group. It was to survey the extent of pollution, consider different options to deal with the situation and then put a price tag on the choices. As a token of the Assembley's seriousness, the Commissioners were given a grant to carry out their mandate. In the time honored American fashion, they hired a consultant. 3

On December 13, 1933 the Commissioners released their report. It did not make pleasant reading. The sanitation system was in disturbing condition. Of a Metropolitan population of over 600,000 people at least 180,000 had no sewers. 4 It was a "remarkably backwards situation". As things stood now conditions were "extremely undesirable... a menace to public health." 5 The Field's point plant was described as "crude" and old fashioned.

The Commissioners offered an ambitious program to rectify the problems. A Metropolitan Sewage District should be created. It would have stretched from woonsocket to Warwick, from 
Coventry to East Providence. This would have included 18 of the 39 coumities of the state. $87 \%$ of the state's population would have been served. ${ }^{7}$

The Commissioners also discussed funding. They proposed a joint effort by the state ond the federal Public Works Administration. ${ }^{8}$ They must have had their eyes on the millions of dollars worth of public works grants that were beginning to flow from washington, D.C. The price tag, depending on the treatment option chosen, was anywhere from $\$ 14 \mathrm{mil-}$ lion to $\$ 84$ million. 9 (in 1933 dollars)

There are no precise explanation why nothing was done with the report. The money involved probably scared people off. For whatever reason the report was shoved on the shelf to gather the proverbial dust. No one seemed to care.

Over the years Field's Point was not a big issue. The plant recieved two major overhauls. It became a secondary treatment plant in the mid 1930s. ${ }^{10}$ In the 1950s another series of expensive rehabilitation was done. ${ }^{11}$ The plant at Field's Point didn't function all that well; it didn't fail spectacularly either. ${ }^{12}$ As a quiet failure it was not noticed at all.

I I

Providence, like other northeastern and mid western cities, suffered a tremdous decline in its economic base after the Second World War. A steady stream of businisses, middle class and prosperous working class families deserted the city for the suburbs. 13 
When these people left the tax base decreased. The city was poorer; this meant tax revenues stagnated. 14 To keep property tax levies reasonable an insidious pattern of municipal disinvestment arose. Certain city services and facilities were starved of the capital needed to keep them up. One of the city services chosen for disinvestment was the treatment palnt at Field's Point. ${ }^{15}$

John Kellam, a planner with the city since 1950, has statnet $d_{i}$ ed the city $\mathrm{did}_{\wedge}$ a great job maintaining the treatment plant. However, they always did try to keep it up, at least until the Administration of Joseph A. Doorley, Democratic Mayor from 1965 to 1975 .

According to Kellam, Doorley was a politician dedicated to keeping the tax rate low at all costs. His tactic was simple: keep replacements and repairs of worn out equipment to a minimum. Hold municipal salaries down.

This sort of thing happened all over the city, but Field's Point was one of the worst hit facilities. Over ten years the plant simply fell apart. Machinery broke down. It was often repaired by using parts cannabalized from other brokrn down machines.* Kellam stated Doorley used the plant as a patronage dumping ground.

Kellam believes there was at least one instance where the plant was deliberately sabotaged by the Public Works Department. A long time sewage overflow was found to have been caused by a large block of wood stuck in one of the "slots"

* Many sources confirm this charge. 
into which the water would normally flow to the plant. It was a perfect hit. Kellam thought this was no coincidence. He thought it was done to "off load" sewage from a plant that could not handle all the flow into it.*

Whatever they thought of the Cianci Administration's handling of the Field's Point problem, no one disputed the essentials of Kellam's account. Some of the details are, of course, unverifiable.

\section{I I}

1974 was an election year in Providence. Mayor Doorley survived an attempt by the Democratic Party organization to deny him renomination. Unfortunately for Doorley the four way primary left a lot of hard feelings. Many Democrats would bolt the party in the general election.

Doorley narrowly lost. Vincent A Cianci, Jr., who had been a virtual unknown at the beginning of the year, would be the new Mayor. Cianci would be the first Republican to hold the office since 1940. One of the things he inherited when he took office in January 1975 was the Field's Point treatment plant.

* When an electrical power system starts to fail from too much demand the people in charge "off load" parts of the grid. In other words some areas get their plugs pulled to prevent the entire system from collapsing. In the case of Providence Kellam meant a lot of the daily sewage flow had been diverted to prevent the plant from being overwhelmed. 
A Brief Digression into the Political Environment

To understand the contemporary political scene in Rhode Island one must understant the aitical past. What goes on is not only consistent with the past. Current events are often governed by the past and the forgotten politicians of former days.

Rhode Island has a contentiouspolitical life. This is thouroughly consistent with the state's tradition. The state has never been regarded as progressive; in fact its reputation has sometimes been quite disreputable

On May 4, 1776 Rhode Island declared its indepandence from Great Britain. It was the Eirst colony to do so. This is quite possibly the last itme Rhode Island was in the forefront of anything.

Rhode Island's role in the Revolution is outside the scope of this paper. We will leap agead to 1787, when the Constitutional Convention met and exceeded its modest mandate to revise the Articles of confederation. Rhode Island declined to send a delegation to the body that wrote out current Constitution. 1

The events that follwed are well known. The Constitution was drafted. The year 1788 saw furious battles all over the country to ratify the new charter. Except in Rhode Island, which did not bother to hold the necessary ratification convention. ${ }^{2}$

The Constitution was ratifed by the other twelve states. Elections were held and George Washington was elected the first President of the United States. Rhode Island didn't participate. When the first congress convened in New York there was no Rhode Island delegation. 
Rhode Island was regarded as a "pariah" ${ }^{3}$ Not only did the state refuse to join the Union, it did so for reasons President Washington described as "shameful"4 Briefly, the state had hit upon a breathtakingly simple way to retire its revolutionary war debt. The state goverrment issued paper notes to retire its obligations. A creditor who refused to take the state's paper had his account cancelled. ${ }^{5}$ This gave the faction controlling the state no reason to join a federal govermment that had assumed the war debt of the states (and was paying off that debt in hard cash derived from taxes). The new goverment would only be a nuisance. 6

Rhode Island finally caved in. The constitution was ratified by ihe state convention in May 1790. The vote was 34-32. ${ }^{7}$ (the paper money faction had been voted out. The new group was composed, in part, of people who held Continental Congress promissary notes. The new U.S. Congress wouldn't redeem the notes until Rhode Island joined the Union) ${ }^{8}$

The prevailing political mores made reform difficult to accomplish. It was as difficult as pulling alligators teeth. Sometimes the alligator that was the state establishment bit back. There wiwas always a clique in power and no matter what its ideology in the begiming it was soon dedicated to keeping power and patronage.

When Rhode Island finally sent its first delegation to Congress it was still ruled by the Royal Charter, granted over a century earlier by Charles II. It was to remain in effect for years (until 1843). This led to the most spectacular example of the state's political elite's extreme reluctance to dilute its own power. 
The General Assembly had established a $\$ 134$ property requirement to vote. This restricted the franchise to the well off, but for years it didn't seem to matter. When the rumblings of what is now called "Jacksonian Democracy" started to shake the state, at first gently and later massively. it mattered a great deal.

Agitation for constitutional reform began in the 1830's. The main demand of the reformers was universal suffrage for all men (usually all white men). ${ }^{9}$ The forces in charge of state government made no serious efforts to change the situation. As one historian has written, the "once progressive royal charter appeared starkly reactionary when compared to the basic laws of Rhode Island's sister states." 10

Thomas Wilson Dorr, lawyer and son of a rich merchant, was a leader and finally the leader of the suffragists. "When the-charter goverrment continued to support the status quo the reformers decided to simply ignore the established government. They elected delegates to a "People's Convention"; that body drafted the document known.as the "People's Constitution."

The "People's Constitution" was a liberal document for its time; it gave the vote to all white men. It also allowed for a better apportionment of the General Assembly. In a referendum held by the "people" it got nearly 14,000 votes. Dorr, riding high, declared the document the basic law of the state.. His forces prepared to hold elections under the new regime.

This time the Charter goverment gave some. They did so most cleverly. The charter forces organized their own convention. Fram it emerged a proposal to enfranchise all native born white men. Thus a wedge was crafted which split Dorr's supporters. His native born supporters 
had what they wanted. Many deserted the cause, not wanting to put themselves in jeopardy for foreigners. 12

By this time Dorr had been elected "Governor" and an entire slate of officers and legislators had come in with him. When the charter goverment decided to put down the "Peoples Constitution" once and for all the movement collapsed. The charter Governor called out the militia, declared martial law and ordered mass arrests. He appealed to President Tyler for support and got it. ${ }^{13}$

Fortunately not one life was lost during this. When Dorr's band of volunteers was disbanded the "Governor" fled the state. (When he returned he was arrested, tried and onnvicted of treason. Sentenced to life at hard labor he was released within a year. In 1854 the legislature expunged his onvictin:and restored his civil rights. In that same year, 1854, Dorr died, a broken man.) ${ }^{14}$ In 1843 the present state constitutionreplaced the charter. Naturalized citizens were only fllowed to vote after meeting a property requirement. 15

The decades of the 40's and 50's were tumultuous in the 19th century U.S. Rhode Island was no exception. The former charter forces and their political heirs finally found their instrument to maintain power: the Republican Party. The Republicans got an absolute lock on the state goverment in the 1860's. It took a bloodless coup to finally oust them in 1935.

Henry B. Anthony, publisher of the Providence Journal (then as now the state's dominant newspaper) created the state's Republican machine. Called the "Journal Ring" his crew came to completely dominate the state. Anthony used the power of his party and the power of his newspaper to promote his own poltical ambitinns ( he served in the House and 
the U.S. Senate) and those of others. His greatest protege was Nelson Aldrich* who he put into the U.S. Senate. His greatest operative was General Charles Brayton, who inherited the party leadership when Anthony died in $1884 .^{16}$

General Brayton was a member in good standing of the corps of bosses who ran America's political machines a century ago. What Brayton lacked in scruples he almsot made up for in candor. (He once opened a meetting by addressing the "Gentlemen and Fellow Machinists". He also once said "The Democrats are just as bad, or would be if they had the money." 17

Under Brayton (who ran the state while sending Aldrich back to the Senate to run the country) the moral tone of public life hit bottom. After Anthony died even the Journal occassionally broke with the party. The"Blind Boss" had raised vote buying to an art form. (\$35 a vote in a close election, according to Brayton). ${ }^{18}$ It is small wonder one muckraking article called Rhode Island " State for Sale".

Brayton's power base was the legislature, particularly the state senate. Though both houses underrepresented the urban areas the senate was by far the worst case. Each town had exactly one seat, regardless of population. Brayton used his rural based machine to stay in power. (The Democrats occassionally won the House; they never won the senate) .

By the turn of the century the Democrats were starting to show signs of competitivness. This threat of reguzar Democratic Administrations caused Brayton to add a unique refinement to his system: The Brayton Act.

* Nelson Aldrich was the maternal grandfather of Nelson Aldrich Rockefeller. 
Thi:3. Iaw allowed the Senate to reject the governor's appointments and substitute thier own. This reduced all Democratic Governors to total impotence. 18 a

The Republican Acendancy lasted into the 1930's even though their was extreme social and political unrest. Strikes were on the front pages as Rhode Island's textile industry began its long decline. The Bemocrats were totally frustrated in their efforts to reform the state's political arrangements. Then Theodore Francis Green was elected Governor in the Democratic landslide of 1932.

Green was that Rhode Island rarity; a Yankee Democrat. He had been elected Governor late in life after a long and not notably successful career in Democratic politics. ( Green had made his first run for Governor before the First World War) ${ }^{19}$ Like all his Democratic prederessn.Green found himself redered powerless by the Republican's control of the senate. 20

Green and the other Democratic state officers were reelected in 1934. A Democratic House was carried in with them. The Republicans had a two seat majority in the Senate. Green and his allies decided to take matters into their own hands. When the new Assembly convened on January 1, 1935 they acted.

When the Senate was called to order the Lt. Governor, Robert E. Quinn directed that two Republican members stand aside while the other Senators took their oaths. The Republicans realized something was up and tried to bolt. This would have denied the Democrats a quonum. Quinn directed that some Republicans be forcibly detained in the locked Sen- 
ate Chamber while a recount: was held for the disputed seats. (This was perfectly legal) The ricount showed the two Democrats who had contested the seats were the real winners. They were duly sworn in and the Senate got down to business. Business was a wholesale houseclean21 ing of state government. An omnibus reorganization bill remade the state's organizational structure and not incidentally fired many Republican office holders. General Assembly control of the city of Providence, particularly the police force was ended. The entire Supreme Court was fired. (The court serves at the pleasure of the legislature. No Democrat had been appointed to it since before the Civil War.) 21 This meant the Democratic reforms would stand up to Court challenge. By the end of the long day 70 years of Republican control had been ended. The Brayton Machine was dead. 22

The Democrats have rarely been out of pow $: r$ since. 1938 saw the last time a Republican Governor was elected with GOP majorities in both Houses of the legislature. The House has been Democratic since 1940; the Senate since 1958. 23

While the Democratic hegemony has remained intact there have been momenta of weakness. There have interludes when Republican Governors took office, most recently for three terms in the 1960's. In 1976 Governor Philip Noel, an umpopular Democrat, lost to John Chafee, a popular Republican, for the Senate seat vacated by Jhon O. Pastore. In 1980 another unpopular Democrat, Edward. P. Beard lost his Congressional seat to Republican Claudine Schneider. These results indicate vulnerability, but the Democratic Party is still finnly in control of the machinery of state. 
The Machine Stons

When Vincent Cianci took office it was only a matter of time before Field's Point failed completely. ' Much of the plant's equipment was beyond repair; one settling tank was to become so clogged with sludge that a man could walk across it. ${ }^{2}$

There is never a good time for things like this to happen. Fram the city's viewpoint, however, the mid 70's was one of the worst times. The reason: federal legislation like the Water Pollution Control Act of 1972 gave the United States government an unprecedented interest in water quality. The Enviromental Protection Agency (EPA) would simply not permit the city to shirk its responsibility tn treat sewage properly.

The EPA offered incentives to municipalities ti put things right. Planning grants were offered, as were constrixction grants. Nationally these came to billions of dollars. ${ }^{3}$ If a polluter didn't respond to kindness there was the stick; the EPA could go to court to ask for fines and court orders. As a municipal corporation Providence enjoyed no special immunity from EPA Drosecutior.

Simultaneous with the final collapse at Field's Point, the state produced its Section 208 Water Quality Plan. Most of the state was covered by this document. Three years in the making, it identified the Providence sewage treatment plant as one of the very worst polluters in the state. "This report would be heavily relied upon when the state finally intervened. 
By early 1977 some very nasty chickens were coming home to roost. An EPA inspection team found the plant in horrible condition. It bareIy functioned. The advanced decay of the plant was evident to even the most casual observer.* Conditions were descibed as "sickening". The EPA was by this time pressuring the city to start correcting the situation or face court action. 5

Things worsened. The state was forced to close the unper Bay to shellfishing indefinitely. $\bar{\sigma}$ There were many unhavoy shellfishemen.

On June 5, 1977 the EPA finally sued the city in Federal District Court. The agency demanded that the city live up to the conditions of its National Pollution Nischarge Elimination System (NPDES) permit. The EPA and the Cianci Administration settled out of court. A consent decree was signed which gave the city a final deadline of November 23, 1979 to get the plant at an"operational level": that was acceptable. ${ }^{7}$ A civil penalty of $\$ 2500$ per day could be assesed the city if it did not comply.

Late in June 1977 the city held a referendum. The question was: should $\$ 8.5$ million worth of bonds be sold to finance a repair job on the plant. Mayor Cianci supoorted the hond issue. It passed four to one. ${ }^{8}$ The city's independent effort to restart the plant was on.

* I toured the plant four years later. While it was operating ... surprizingly well it was still obviously in an advanced state of decay. 


\section{The Crisis}

The city hired the firm of Charles J. Krasnoff and Associates (CKA) to be project managers of the repair project. That firm in turn hired a number of subcontractors to work on various phases of the job. ${ }^{1}$ Throughout 1978 and 1979 they worked very hand to get the plant in shape. It was during this period the "crisis" occurred.

With the plant completely non-functional during repairs the only treatment sewage recieved was chlorination. ${ }^{2}$ Greaseballs* were turning up; they were very umpleasant. Places like the Edgewood Yacht Club, a berth for the boats of some of the state's elite, was sullied. This awakened a vocal and affluent constituency to water quality problems.** For the first time in a long time sewage treatment and the general poor quality of the waters of the upper Bay were consistent front page items in the Providence Journal. Some people began to beat the the drum for state intervention. The state, led by Democrat J. Joseph Garrahy, did not seem eager to get involved. As late as July 29, 1979 the Governor pledged state action only if public health was threatened. "But I don't wast to get involved in the city's business," he said. ${ }^{3}$ This did not stop officials of his Administration from publicly attacking the city's handling of the repair project. Nor was the city, usually spoken for by Mayor Cianci's top aide, the colorful Ronald Glantz, reluctant to respond in kind.

* Globs of grease congealed arouni solid matter.

** One of the Providence Journal's editorial writers for instance, is a boat owner. 
The city-state feud was exacerbated by the growing political rivalry between the Mayor and the Governor. Both had been impressively reelected in 1978. Garrahy, with a two year term, was expected to try for a third tern in 1980. Mayor Cianci would be his Republican opponent. This competetion overshadowed evertything. It still colors the city's relations with the Narragansett Bay Commission.

As the words flew work at the plant continued. According to one participant the work was "difficult" 4 given the deterioration of the equipment.

The war of words was fought outin the pages of the Providence JournalBulletin newspapers. Glantz, a iather unhibited man given to crude responses, would fire away for the Mayor. The state's usual spokeman was W. Edward Wood, Director of the Department of Environmental Management. (DEM)

For example: When the state issued an order to the city, through Wood, to speed up plant repairs, Glantz called up"baloney". He implied the shole thing was politically motivated. The Journal dutifully printed the exchange. 5

III

The Journal was a major reason the pot kept boiling. Pollution of the Bay may not always have been front page news, but it always got good play. Criticisms by environmentalorganizations like Save the Bay and the Coalition of coastal Communities (made up of most of the state's coastal towns) found their way into print, The city's percieved slowness in putting the plant on its feet drew more than one scath- 
ing editorial. Editorials like "Raw Sewage Intil November? An Intolerable Prospect." 6 may not sway too many people. IT did draw attention, though, which was surely the intent of the management.* It was a sign that a powerfill head of steam was building up for someone to do something.

When the city claimed construction could not be speeded up the paper responded. "Of course it can be speeded up. Any construction project can be speeded up..." The Journal wanted a declaration of emergency. The editorial concluded " with a genuine pollution crisis now at hand, the state's elected leaders are duty bound to insist upon a crash program of speeded up repairs. They have dragged their feet far too long." 7 It seemed a warning to those"duty bound" officials, particularly the Governor, that the Journal might start to aim the editorial guns at them.

The newspaper did have a point. Thestatedid confine itself to criticism of the city. In public people like wood offered nothing constructice. They certainly did not seem eager to take on the thankless jab of plant rehabilitation on themselves. The Governor ducked the issue whenever he could.

He might have successfully done so forever, for stern editorials ans environmentalists' protests do not a groundswell make. Then something occurred which allowed the critics to brilliantly dramitize their issue. The pressure on Garrahy to act would be irristable.

* The Providence Journal is the only statewide newspaper. The Journal Corporation is a major instate investor. It owns two radio stations, a cable television company and is a major investor in the Biltmore Hotel. 
The Crisis II: The Dam Bursts

On July 16, 1979 the final breakdown occurred. The chiorination system broke down; millions of gallons of raw sewage were pouring into the Bay every day. The system breakdown was an accident ${ }^{I}$, but that didn't matter. The city's critics now had a live issue. The state had been embarrassed too, They knew about the breakdown for ten days before it was made public.

In an editorial entitled "Narragansett Bay down the Drain" the newspaper called the incident a "political bombshell". The editors criticized DEM for sitting on the news; once again the city's slowness was denounced. In both instances the paper wanted to know: Why? ${ }^{2}$

Governor Garrahy's attermts to keep out were becompi politically untenable. On August 1 the story got prominent coverage on pages one and three. Page one discussed the newly issued Section 201 facilities plan done by Anderson-Nichols, an engineering firm. This document covered the price of repairs for the entire Providence system. Prominent coverage was given to the price tag: $\$ 242$ million. ${ }^{3}$ Page three reported the Conservation Law Foundation wanted a special master to take over the plant. In the same story David Strouss, of the Coalition of Coastal Cormunities, also supported a special master, citing " the lack of someone taking charge." 4

Trudy Coxe, executive director of Save the Bay, by far the state's most prominent environmental group, wanted some single "authority" to have control of the plant and its system. 5 
The Journal called the breakdown a crisis. It certainly reported it as one. On August 2 the Journal quoted Dennis Nixon, URI professor and lawyer for the Shellfishermen's Association, as saying, "the fact that we tonight are prepared to write off the upper Bay for a hundred years is a pretty drastic step." 6 This was pretty strong stuff.

For its part, the city had trouble defending itself. Ronald Glantz (who this writer can safely say was not the best man for the job) worked on the best defense is offense principle. Glantz attacked (and to this day attacks) the political motives he thought were behind the criticisms. 7

\section{III}

The Governor finally acted: Garrahy announced he would appoint a task force of politicians, professionals and environmentalists to study the problem. ${ }^{8}$ The Governor remianed cautious. " Perhaps a new authority need be created. Perhaps it is time to review the possibilityof a statewide approach to all the stafe's sewage treatment pro- ". blems." 10 The Governor's statement was not enthusiastic. Garrahy had decided to appoint this task force without oonsulting the city.

This became knowa the next day, when Cianci released his own plan. He wanted an independent city agency patterned after the highly regarded (and autonomous) Providence Water Supply Board. The Maynor requested the General Assembly (both houses of which have huge DemocratIc majorities) enact the required legislation at an upcoming special 
session. ${ }^{11}$ Cianci then revealed that Garrahy hadn't consulted him on the task force, though he claimed he didn't think the Governor was trying to undercut him. Cianci ended up by saying he didn't want the plant to become a"political football". 12

\section{TV}

By August 12 the Journal was speculating whether the sewer problems would become a 1980 campaign issue. The political columnist of the day revealed that the task force had been a rush job; that explained in part Cianci's not being consulted: The columnist also quoted W. Edward Wood, of DEM. Wood was giving the party line. "Suddenly two vears after he becomes Mayor it goes downhill and goes downhill and stips operationg. So I don't agree it's a 100 year old problem he's inherited."13

Wood's statement was hard, not to say dishonest. Cianci did inherit a bad situation. Wood's statement, coming as it did from a prominent member of the Democratic Administration, demonstrated how the issue was becoming politicized. The tone and temper of the exchanges show that both sides saw the issue as dangerous.

At this point of high tension both sides backed off, at least in public. The Governor and the Mayor had a brief meeting. They agreed to work together to deal with the water pollution problem. Despite his new task force the Governor agreed to support Cianci's plans for a city authority. The Mayor was appointed to the Governor's task force and agreed to ooperate with it. 14

* Two and a half years later Ronald Glantz is still very annoyed by this. 
Garrahy announced the final composition of the task force. It was to be chaired by Louise Durfee. Miss Durfee had several credentials for the job. She was a lawyer and an environmentalist (a founding member of Save the Bay) and a Democratic politician. The taciturn Durfess is not a woman to be trifled with; her presence gave the task force credibility with both enviromentalist and politicians. 15

House Speaker Edward Manning had already promised the Mayor his reform package would be taken up.16 on August 22, 1979 the Assembly leaders announced a special session would be held on september 20 . True to their word it was announced that the Mayor's bill would be one of the things considered. 17

\section{$\mathrm{V}$}

However, no bill came from the city for the General Assembly if consider. It bogged down over a dispute about administrative structure. The Mayor wanted a brand new city agency; a number of City Council Democrats wanted the plant given to the Providence Water Supply Board. ${ }^{18}$ An impasse developed. This bothered both the Mayor and the Governor; they were eager to get some sort of reform program rolling. ${ }^{19}$ On September 19 the Journal reported no agreement could be reached between the Mayor and the City Council. No bill would go to the special session. 20

This left the field to the Governor's task force. No action requiring Assembly approval was going to be considered until the legislature convened for its January session. As far as this issue was concerned, the Cianci Administration was to be shoved first to 

the sidelines, then to the fringes.

VI

The Task Force got right into its work. Meanwhile the city and state continued their front page fencing. The state DEM continued to attack the city's competence to run the plant. At one point DEM suggested a private finm manage Field's Point. ${ }^{21}$ Just where this private firm could be found DEM didn't say.

Afew days later the city and state accussed each other of stalling. Once again the city's competence was called into question. This did not help the plant's staff. They felt they were being set ip to be scapegoats.*

On November 9, 1979 the Democratic Attorney-General Dennis Roberts sued the city to enforce chlorination requirements. Since nobody suggested the city was willfully dumping raw sewage Robert's action was a bit superfluous. Glantz called Robert's action"political" and wondered aloud why the state didn't go after problems in Democratic controlled Warwick and Newport. " They are like the Indian trailing a tree behind himself to cover his own tracks." said Mr. Glantz. 22

VII

It was finally time to restart the plant. On November 19, 1979 Mayor Cianci did so. ${ }^{23}$ It was four days before the court ordered

* One well informed person told me these criticisms did have some basis. A "tiny" minority of workers couldn't or wouldn't do their jobs. He thought it fair to point out the staff waspoorly paid, criticized often and held in low esteem. There was a serious morale problem at the plant. 
deadline. There was still a way to go before the plant was working well. The biomass, the collection of microbes that feed on sewage and make it safe to discharge, was not ready. ${ }^{24}$ It was plain the city would not be in compliance with the court order; this would put the city back in court in 1980. It would be some time bebore Krasnoff and the contractors got the plant to work consistently well. 25 
Toward a Bay Comission I: Was State Intervention Justified?

Once the city failed to come up with a plan for an autonomous city agency the responsibilty for proposing reform was left to the Governor's Task Force. Working through the autum and early winter they strove to produce a report that could be acted upon at the General Assembly's January session. The questions are: was their work needed? Were their eventual recommendations cesirable?

According to three key task force members this writer interviewed* there was no question of the city being allowed to maintain control over the plant in any form. None of them, from the blunt Louise Durfee to the more diplomatic Gary Sasse had any faith in the city's ability to manage the plant or maintain it properly. All thought the reality of the city's poor tax base also precluded raising the capital needed for the program they envisioned; all were critical of the city's management practices. They were skeptical things would get better soon.

Aides to the Mayor $\star$, for their part, were critical of the Task Force and suspicious of its motives. Ronald Glantz was particularly outspoken on this point. Both made it clear they thought the Task Force was not really interested in working with the city towards a settlement which reflected well on the city and state. Both sides are right.

The criticisms of Ronal? Glantz and Robert Chase have some fac-

* Lollise Durfee, Chair of the Task Force; Mary Kilmarx, Chair of the General Assembly Joint Committee on the Environment; and Gary Sasse, Executive Director of the Rhode Island Expenditure Council

** Ronald Glantz and Robert Chase 
tual basis. The task force members interviewed all agreed their minds had been made up on several points: (1) some sort of state agency should take over the plant; (2) for whatever reason the city had done a miserable job in the past, was not doing a good job presently and would probably botch up the future, because (3) the city did not have the wealth to build a new plant and maintain it according to the Section 201 Facilities Plan. (Expenditure of a quarter billion dollars might be called for ${ }^{l}$

All three tasi force members criticized the city for not cooperating with the task force. The city had very little to do with shaping the policy recommendations of the group. Gary Sasse could not remember the name of the Mayor's man on the Task Force. (Jcseph Rotella, a city lawyer) ${ }^{2}$ He did remember that Rotella said and did very little.

Sasse criticized the "lack of policy imputs"from the Mayor. Miss Durfee thought no one "was on top of things" at City Hall. (This was a frequently and widely heard ongoing criticism of the Cianci Administration's handling of this issue)

Robert Chase, who represents the Mayor on the day to day affairs of the Water Pollution Program, was in turn critical of the whole process which brought the task force about. The city didn't play much of aa ro..e because the city's wish for an independent city agency was not considered. The lack of respect task force members had for the city goverment was very evident during interviews. Given this there is still a question: Once it became obvious a state takeover was in the works, why didn't the city cooperate to assure an orderly transfer? The question is still unanswered.It is certain the Task Force 
would have welcomed the city's participation towards this particular end.

Glantz and Chase consistently questioned the motivations behind the creation of the Task Force and its recommendations. This is an important theme. for whatever the truth of the matter, the belief in a desire on the part of the Democratic Governor to embarrass the Republican Mayor (and prospective opponent) affected the actions of the Mayor and his men.

As it happens, the position of Chase and Glantz does have some validity. Mary Kilmarx, at the time a Democratic State Representative from the affluent East Bay Community of Barrington, stated. that the Garrahy-Cianci rivalry had "some" influence over the Task Force procedeings. She had no doubt things would have gone much smoother had there been a Democratic Mayor in City Hall. This did not change the fact she was there primarily to deal with a disturbing problem: the continued degradation of the waters of Narragansett Bay. She did admit though, she enjoyed the"bonus" of being able to score some political points off Cianci.*

Robert Chase, by way of defending the City Administration, says the total picture must be considered. To Mayor Cianci, an ambitious man, the plant was just one of many issues- and not one many of his constituents cared about. Why should an ambitous politician like Cianci get too far ahead on an issue that could do little for him at best and hurt him at worst (because of the money involved)? It is easy for people on the "outside" with very narrow constituencies to please to demand action. It's another thing altogether for an

* Ronald Glantz was particularly unflattering towards Mrs.Kilmarx. He depicted her as a tool of the Governor and sais "now she has a job with the state" (the Public Utilities Commission). The very plain implication was that it was her payoff. 
embattled big city mayor to do so. The plant was an "East Side" issue (the city's most affluent neighborhood) and not a big concern to most of the city.

Chase and Glantz saved their roughest comments for the Providence Journal, who they believed trumped up a phony crisis to force a state takeover. When the ahlorination system broke down reconstruction was already well under way. All that was needed was a little patience * and the situation would have been well under control. To this day they believe the Journal does not give the city the credit due it for getting the plant running "as well as it is capable of running".

This was the soundest argument put forth by the Cianci Administration. The city did get the plant going. The "crisis" had long since passed by late 1980. Very few people have given the city or its contractors proper credit for the job.

Chase and Glantz believe the city was made a whipping boy by a very narrow constituency of envirommentalists (aided by opoortunistic politicians) who found it a dramatic issue to rally around. To this end the city's pollution problems were consistently misrepresented and the city's accomplishments ignored. Both wanted to know, by way of a rhetorical question, how an 1899 model šewage treatment plant could be expected to function up to 1980 standards in any event. This view is apparently shared by the Mayor. This writer heard the Mayor defend hisadministration's competence, pointing out the city no w had a "brand new Model T" to work with.

Most critics of the city interviewed would, if pressed, concede

* By late 1980 the plant was functioning surprisingly well, often excedeing 1983 EPA pollution guidlines. 3 
the physical limitations of the plant. This, however, tended to be glided over quickly. None had a great deal of sympathy for the Mayor's political problems. Politicians like Mary Kilmarx did seem to have a little. Trudy Coxe had none at all. She was very harsh, claiming that save the Bay had been"rebuffed and lied to", forcing her and like minded people "to take off the gloves". When asked to comment on Mr. Chase's defense of the Mayor she called it "shortsighted and narrow". As to the problems of running a big city she said, "Tough. Buddy wanted to be Mayor."

Unlike most other people, Miss Coxe wouldn't accept the city's relative poverty as a defense for its shortcomings. "Where were the user fees?" she asked. ( Robert Chase would no doubt point out the user fees were another hot issue. They may be desireable, but who wants to be the politician who gets out and leads the way? Trudy Coxe would no doubt say "tough".) *

Chase admitted the city had made mistakes. They were, in his view, mostly in the realm of public relations. The city was not "prepared" for the breakdown as well as it might have bee. After the breakdown, which was depieted as a catastrophe, the city did not do enough or could not do enough, to affect the perception that the city government was totally inept.

On the other hand both Glantz and Chase offered an argument that was rather disingenuous, $\mathrm{n}$ ot to say silly. Both

* This writer's observation is that Miss Coxe is not very very sympathetic to the much put upon Providence taxpayer. At a Citizen's Advisory Committee meeting in the summer of 1981 the subject of Providence's taxes arose. A group of taxpayers, led by Mrs. Rikki Sweeney was fight- 
downplayed the importance of the fecal matter dumped into the Bay as a result of the plant breakdown. Both claimed that the heavy metals passing through the system, into the plant (thereby disrupting the biomass) and out into the Bay bottom muck was a bigger problem. (the heavy metals mostly come from the state's jewelry industry). Heavy metals certainly are regarded as a major source of Bay pollution. Yet to pretend that raw sewage is not a big problem when it is dumped into public waters is a grotesque position.*

The establishment of a state-city task force with some influential members to examine Bay pollution problems was a long overdue development. Some sort of reform was needed, as the Mayor himself had already admitted.

However, the city does not feel it was well treated. This certainly got things off to a bad start, for their feelings in this instance have some justification. There is still this problem: Why couldn't the Mayor get together a proposal for the city agency he claimed to want? This question is very pertinent as the current administrative arrangements have caused the Mayor much grief. Having lost the chance for a city agency why didn't the Cianci Administration bow

ing a special extra tax levy voted by the Providence City Council. Miss Coxe at one point asked, "Who is this Mickey Sweeney anyway?"

* Ronald Glantz told this writer, "Shit doesn't hurt fish. Fish digest it." 
and cooperate completely with the task force to get rid of a large, expensive albatross?

At least one individual close to the situation thinks the Mayor just doesn't care very much about the sewer plant. In this observers view, this explains the inattention on the city's part when it came time to work out a transfer of the plant. If Cianci really is indifferent towards the sewer system problems and the attempts to work them out, he then deserves all the bad press and political fallout he has had showered on him in the last two years.

\section{III}

The Governor and his task force may have been pressured by a bogus crisis. There is certainly evidence to support that view. *The city, however, did not take advantage of the opening the Governor left it: his offer, backed by the legislative leaders, to support a new city agency if the city government could only get itself organized and produce a bill to enact.

Governor Garrahy did not intervene merely to embarrass the Mayor. He did nothing until forced to. He was not enthusiastic when he finally did involve himself. He certainly did not committ himself to a state takeover of the plant when he appointed the task force. He should have called the Mayor and talked to him before he did it, but that's another matter.

* One state House hand contacted (and who prefers anominity) says it's a common belief around the state House that the Governor is unduly sensitive to pressure from the Journal. Of course very few of these people ever get pressures by the "ProJo" themselves 
When the city failed to act the Governor was left with little choice but to act himself, even if his response was hasty. That was only a basic response to political reality. He did his best to avoid it. The Governor hit the ball back out to the city as quickly as he could; Mayor Cianci and his men botched the catch miserably. 
Toward a Bay Commission II: The New order Takes Shape

It has already been noted that the Governor's task force had no doubt they would opt for a state takeover of the Providence sewage treatment system. Having made this broad policy choice several questions remained to be answered: What was the extent of the pollution problem? What effective, affordable measures could be taken to combat pollution? What would be the format of the new agency? How much state support would be offered and how would the money be raised?

The task force, relying heavily on research done for the Section 208 Water Quality Plan, found major degradation by both "conventional" and "unconventional" sources. 1 Conventional pollutants are $\mathrm{BOD}_{5}$, suspended solids, settlable solids and coliform bacteria. ${ }^{2}$

$\mathrm{BOD}_{5}$ is biological oxygen demand. Simply put, when certain substances are dumped into water they stimulate biological reactions which use up the dissolved oxygen. If enough dissolved oxygen is used the water "dies", i.e., it cannot support most marine life. The higher the BOD $_{5}$ loading the worse the problem. Settleable solids and susoended solids are just that- material that either settles out to the bottom or remains suspended in the water.

Coliform are organisms used to measure for undesirable bacteria. The presence of coliform, harmless in of itself, is an indicator of potential health problems if the count 
is high enough. 3

Unconventional pollutants tend to be things like metals from industrial operations and urban runoff. According to one University of Rhode Island marine scientist, runoff from the streets is loaded with metals and chemicals. 4

Municipal treatment plants on the Bay were found to contibute 758 of $\mathrm{BOD}_{5}$ and $69 \%$ of suspended solids. Of that amount the Field's Point plant ultimately contributed $62 \%$ of the $\mathrm{BOD}_{5}$ and $46 \%$ of the suspended solids. 5

No figures were given for unconvential pollution sources; no figures are available. It is a very new area of research. Though there is no useful quantified data available a presentation given by Dr. Eva Hoffman, of URI, left no doubt these sources of pollution do a lot of damage. Both point source (specific outflows into a body of water) and nonpoint sources (runoff from streets and fields; used motor oil dumped into sewers) contribute unconventional pollution. 6

The state DEM had divided the Bay into five di fferent segments. Their waters were classified as follows:

Class SA: suitable for shellfishing and all sea water uses

Class SB: suitable for bathing, shellfishing after depuration and fish habitat

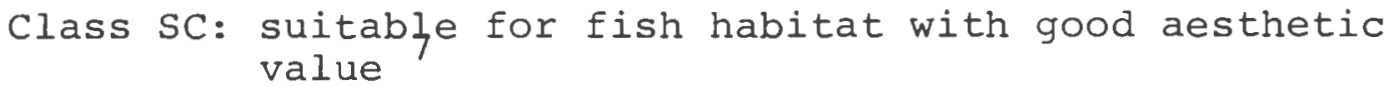

The task force found that if present conditions persisted only the waters of segment Five (the lower Bay) would be open to all recreational and economic uses. ${ }^{8}$ Shellfishing would 
9

not be allowed in segment four. No shellfishing or bathing could be allowed in segments one through Three; even if the entire Providence facilities plan the under consideration were implemented this would remain true for first three segments. 10

If the Providence facilities plan were to be completely implemented the main impact would be on recreational boating, fishing and aesthetics. The improvement here would be general. Shellfishing would be improved; more beds could be opened.*11

\section{III}

Any solution would be costly. Total spending requirements for upper Bay treatment plants and sewer lines were pegged at $\$ 874,135,000$. Providence alone would need $\$ 226,000,000.12$ Task force member John O. Pastore, a former U.S. Senator and esteemed elder statesman** called the figures"amazing".13 Amazing or not the numbers were certainly intimidating in a small state like Rhode Island.

For several reasons the task force members concluded the cash requirements were simply beyond the capacity of the City of Providence. Even assuming a liberal funding situation in Washington, the quarter billion dollar providence facili-

* Ironically when conditions improved enough in 1981 to allow some long closed upper Bay shell fish beds to open the resulting glut depressed the market. The shellfishermen were very unhappy about this.

* * In 1964 Lyndon Johnson toyed with the idea of making Pastore his Vice President. 
ties plan would take four years to implement. 14 A more realistic view of future funding possibilities meant a twelve to fifteen year program was more likely ${ }^{15}$ This could be brought about if construction grants were maintained at 1980 levels. 16 This was an uncertain prospect in late 1979, when the Reagan Administration was just one of Jimmy Carter's bad dreams.

The task force thought some kind of fiscal plan allowing for an acceleration of the four phase 1979 Providence facilities plan was in order:

" In light of the continuing degradation of " water quality in the upper Bay, the Task Force finds that a funding program to accelerate the implementation of "projects to clean up the Bay is essential."17

The task force recommended, given the likelty funding constraints, that priorities be established. The project should be implemented in separate, independent stages one building upon another. This was unavoidable given the limited ability of both the state and the city to produce cash.

The task force found that an attempt to implement the facilities plan quickly, with a $90 \% / 10 \%$ state/federal split of funding would lead to a gigantic bond issue of $\$ 196,000,-$ 000. 18 This would be a large amount in any state; in Rhode Island it was staggering.

The task force found this single bond issue would double the state's bonded debt. 19 This could do tremendous damage to the state's credit rating. The political obstacles to such 
a bond issue were tremendous. As a practical matter the task force did not find asking for that much money a real option. Under that plan the city alone would have to come up with $\$ 21,800,000.20$

IV

The task force stated its lack of faith in the city's ability to operate and maintain the plant. After reciting the by now standard litany (badly operated, poorly maintained, inept staff, etc.) 21 they found the job beyond any one city. It was a regional problem which cried out for a regional solution.

the task force made it clear the city Department of Public Works should have been relieved of the responsibility for theplant a long time ago. A brand new administrative agency was needed. 22 A regional agency modeled after the Blackstone Valley District Commission was suggested. An agency of this type could manage the reconstruction projects, levy user fees, employ a sound management with a higher calibre of employees, promulgate regulations and wield enforcement power. "Equitable representation" of affected interests was necessary. Possibly the new agency could eventually merge with the Blackstone Valley Commission. 23

\section{$\mathrm{V}$}

Having established a data base and drawn some conclusions 
the task force proceded to recommendations Broadly, there were three items of immediate consequence.

First, the task force called for the creation of a state chartered agency similar to the Blackstone Valley Commission. It would represent all interested communities and would also include citizens and interest groups. 24

Second, the task force called upon the state to issue $\$ 81.7$ million worth of general obligation bonds to finance and accelerated construction schedule. The task force suggested the state and the new agency split the amortization costs on a $90 / 10$ per cent basis. 25

Third, the task force wanted the money used to implement Phase II of the four phase facilities plan. (Phase I had been the interim repair project financed and implemented by the city). Phase II called for a major reconstruction of the plant at Field's Point and construction of Combined Sewage Overflows 2 and 9 ( $\mathrm{CSO} 2 \& \mathrm{CSO} 9)$ * an extensive improvment of the plant combined with the construction of the cSOs were evaluated on a cost/benefit basis. It was found a major improvment would result at an affordable cost. 26

The task force asked a bill be drawn up, presented to the Assembly and enacted quickly to implement the above proposals.7

* CSOs are subplants designed to hold and treat the excess water generated by storms.These waters can overwhelm a combined system (a system where the storm sewers and the sanitary sewers are one and the same) like Providene's during a major rainfall. The overflows caused by storms are a major source of pollution of Providence area waters. 
How were these numbers arrived at? According to Gary Sasse, whose organization acted as staff to the task force, they came out of a computer generated hat. Once a bond issue was decided on the State Budget Officer, John Murray, was called in. His agency cooperated with the task force completely. This was critical for the Budget office's support was vital to passage. As the guardians of the state's fiscal integrity they could sink any big spending program quietly and behind the scenes if they chose to.

Working together Sasse and Murray determined the minimum amount the state could contribute and still be large enough to but a significant improvement in water quality. After some work with the budget office computers the task force's figures were arrived at. This was an amount which could buy better water, be a bearable debt and have a chance at political acceptability. 28

\section{VII}

By late January the essence of the task force recommendations were becoming public. ${ }^{29}$ Cianci reiterated his support for some kind of regional agency. 30 In February the task force released its report. Garrahy backed it, making its approval a major priority of the 1980 legislative session. 31 The city administration was strangely silent, save for Mayor Cianci's faintly ominous statement that he wouldn't "give the plant away" to any new agency. 31 
The Grand Coalition and a Nonissue Issue

The arrival of 1980 meant the eagerly awaited struggle between Cianci and Garrahy for the state House could formally begin. Both the professionals and those who politics as a spectator sport expected an engrossing, close contest between two popular and experienced politicians. The bill to create the Narragansett Bay Water Quality Management District Commission and commit the state to selling an $\$ 87 \mathrm{mil-}$ lion bond issue to finance it was also expected to be controversial. The state had never attempted anything on this scale by itself.

Neither expectation proved correct. The campaign was a dud. The opposition that might have been expected toward the bond issue never materialized as it rolled to victory.

The Governor was as good as his word. Louise Durfee, working closely with DEM and the Governor's staff drafted a bill for introduction into the General Assembly. ${ }^{1}$ A Rhode Island Governor of the Democratic Party will usually get his way with the Democratic Assembly if he absolutely, positively insists. He did insist; this meant the bill would eventually pass.

The Governor was no doubt motivated to serve both the public interest and his own poltical interest. The Bay seemed a mess; something had to be done about it. The Field's 
situation was a "bombshell". With vocal environmentalists and the state's leading newspaper supporting a state takeover it was a politically attractive thing to do. The issue, in short, could be defused.

On March 14, 1980 Senator Joseph Gendron, the Majority Leader, rose from his seat to introduce the Governor's bill. It was given the number $80 \mathrm{~S} 2877$ and assigned by the President of the Senate to the Joint Committee on the Environment. The bill was on its way to passage.

On March 20 the Joint Committee referred the bill to the House Finance Committee. A senate bill was, in effect, sent to the House without the usual formality of senate passage. All legislative staffers contacted thought this procedure was "very unusual". 3

On March 25 the Finance Committee reported the bill out onto the floor of the House. Only the elected representatives had seen the bill. The committee professional staff had nothing to do with it, ${ }^{4}$ This left no doubt the decisions regarding this bill were coming down "right from the top" (says one source who prefers not to be named) That same day the House sent the bill back to the Joint Committee, chaired by Mary Kilmarx, where it was redrafted. 5 It took the Joint Committee a month to accomplish this. 6

During this time the Cianci Administration made its position known regarding the new commission. It did not support it. Robert Chase and Ronald Glantz made the short trip up to the State House to testify. Glantz denounced the 
bill in very strong terms. Glantz claimed the bill was too much of a rush job. A solution was being offered when we hadn't defined the problem. Glantz called the program "an absolute fraud, based on a lie." 7

Mrs. Kilmarx' attitude was probably typical of her legislative colleagues. She was very much irritated and offended by Glantz. She thought the city had had ample opportunities to shape the Garrahy program. It was too late to junk the work done and start from scratch.

Her stand was probably justified. Glantz did come in and make "unreasonable demands". Most notable was his wish that the city take over the entire Providence system, including the "laterals" (laterals are the individual tie ins to the system) This was something the state was not prepared to do.

Two years later Glantz still ridiculed the whole Bay Commission. He didn't think it would accomplish much. He called it a "joke" and "an open sewer into which to pour money." 9

These latter statements are more invective than criticism. Yet some of his complaints should be considered. It was a rush job. There was not much study. All participants agreed the Assembly rushed it through because the Governor demanded it. Gary Sasse states there was no need for a thorough legislative review; the "administrative evaluation" had been sufficient. More review by the Assembly "would have been redundant"! Maybe so. A case can be made, however, that the 
General Assembly abdicated its responsibility to be skeptical of the programs of the Executive.

\section{III}

The city's position didn't count for much in the state House. "Buddy" Cianci was as influential up there was a Cardinal in the Kremlin.

- In any event, prolonged opposition to the Bay Commission and the bond issue was not a tenable position according to Cianci's men, Glantz and Chase. The environmental groups were as unforgiving as they were tenacious. The Providence Journal was firmly behind the new Commission. With the popular Joe Garrahy and his dominant party behind it too the pressure was too much to resist. It was an "apple pie issue" 9 that could not be bucked without risking serious political trouble. This meant that even though Ronald Glantz thought the bill "sheer stupidity" that "would never work" Mayor Cianci ended up supporting the takeover. This meant the front supporting the bond issue was a seamless amalgam of interest groups, business, the news media and both major parties. The Grand Coalition was born.

On April 27, 1980 the bill began the sprint to enactment. The Joint Committee reported the bill out to the House once more. By this time it was now called 80 S 2877 substitute "A" 
The bill had been amended somewhat in committee, but the essentials of the task force recommendations remained; at least one provision of the new bill was drawn with partisan considerations in mind. 10

On that same day the House once again sent the bill to House Finance. Once again the professional staff never saw it. ${ }^{11}$ The Finance Committee reported out the bill on May 7 . By this time the General Assembly was in the throes of final adjournment. On May 8 the bill was placed on the Calendar for action the next day. 12

May 9 was the last day of the session. The U:ll flew, passing the House 66-0.The bill was taken across the Rotunda to the senate. It was passed in concurrence, a process which surely didn't take more than a minute. ${ }^{13}$ The vote was 45-0. The bill was taken to the Governor, who signed it without ceremoney the next week. 14

The Bay Commission was now chartered by the state. The bond issue would be presented to the people in November.

\section{$\mathrm{V}$}

The Act, whose short title was "The Narragansett Bay Water Quality Management District Commission Act" became Chapter 342 of the Public Laws of 1980. In the preamble the Assembly found:

" There exists in the Providence metropolitan area and Narragansett Bay severe water quality problems resulting from the discharge of 
pollutants, conventiongl snd unconventional, into Narragansett Bay

" It is furthur found and declared that Narragansett Bay may be the greatest natural resource of the state...

" It is furthur found and declared...that... local government in the Providence metropolitan area have been unable to cope properly and immediately with pollution discharges...

" It is furthur found and declared that the most efficient and effective method to combat the discharge of pollutants is to create ... a Commission... to be charged with the acquisition, planning, construction, financing, extension, improvement, operation and maintenance of publicly owned sewage treatment facilities in the...District" 14

The Assembly chartered a"public corporation of the state having a distinct legal existence from the state and not considered a department of state governmenr."15

It was granted the customary range of public powers, including the ability to acquire land. ${ }^{16}$ The Governor was authorized to advance the Commission up to $\$ 3$ million in state funds. ${ }^{17} \$ 250,000$ was appropriated immediately to cover the Commission's start up costs. All money advanced would be repaid the state when the Commission was fully operative. The Act called for a Commission of thirteen menbers. Four were to be appointed by the Governor, two by the Mayor of Providence * one each by the Mayors of North Providence and Johnston (whose towns are also served by the Providence system). The Speaker of the House and the Senate Majority

* This is a very sore point with Mayor Cianci's aides. They think the city should get more seats. 
Leader appointed two apiece. The state Budget Officer served ex-officio. This meant the Governor did not control a majority of seats on the commission. ${ }^{18}$ This was done quite deliberately, with partisan political considerations.

According to Mary Kilmarx, the General Assembly did not want Mayor Cianci to have any control over the Commission should he be elected Governor.(this seemed a good possibility in the spring) So the Governor was given just five of thirteen seats to fill. This lead to a situation which embarrassed the Bay Commission to no end.

The Assembly specifically charged the Commission with the responsibility to acquire the facilities at Field's Point. To this end the Commission was authorized to assume up to $\$ 14$ million of . Iongterm debt carried by the plant. 19 Essentially the city was to be reimbursed for its interim repair job. The Act authorized the issuance of $\$ 87.7$ million worth of general obligation bonds to finance the reconstuction work. Of the principal the state would repay $\$ 73,641,000$; the Commission would be responsible foe amortizing the remainder- $\$ 14,059,000$. Should the Commission default on paying its share of the debt the state would step in and assume responsibility for it. Assuming no defaults, the state would retire $84 \%$ of the bond issue, the Commission $16 \% .20$

The Assembly set November 4, 1980, Election Day, for a a vote by the people on the bond issue. If the people defeated the bond issue the commission would go out of business on June 30, 1981, unless the Assembly decided otherwise. 
What would happen next was up to the people.

$$
\text { VI }
$$

Some supporters of the bond issue were wary of the public's reaction. After all it was the biggest bond issue ever sought by the state. 22 The voters had not been kind to most bond issues in recent years.

Trudy Coxe didn't have the confidence in the people's judgement in 1980 that she expressed in 1982. She was quoted in the Providence Journal as being very worried about the referendum's prospects. Miss Coxe did not want a November referendum. She preferred a vote in late June when, sine said, voters are more aware of water pollution issues.

It is perhaps no great coincidence that the late June referendum is a traditional Rhode Island ploy to sneak through bond issues that are not regarded as popular. The conventional wisdom is that the hard core supporters of a question can carry the day in a predictable light turnout.

Mary Kilmarx, quated in the same article, eschewed Miss Coxe' calculated ingenuousness. She thought the bond issue didn't have a "chinaman's chance" in November. 23

Gary Sasse was worried by the lack of a centrally directed campaign for the bond issue. He organized a committee and enlisted a public relations firm. Financial support was sought. The Governor pledged his support and agreed to help raise campaign funds. 24

On October 1 the Journal reported the Governor's appeal- 
to the people to support the bond issue. ${ }^{25}$ Garrahy was by this time assured of re-election; he had a glut of political capital to expend on the issue.

\section{VII}

He could be assured because Vincent Cianci's campaign had turned into the most dismal flop of recent memory. The reason: Providence's shaky financial situation had finally started to become unglued in the summer. The details are not relevant to this story; it suffuces to say that the city was running out of cash and carrying a large, illegal cumulative deficit. The Mayor looked very bad since there was no denying he bore the major responsibility for the situation. If the Governor ever toyed with the idea of making the Field's Point mess a campaign issue (this writer has no idea whether or not he did) it was no longer neccessary. Cianci handed the Governor a much hotter issue.*

The Governor enjoys the reputation as one of the nicest men in state politics. This did not stop him from going right for Cianci's jugular. He hammered after Cianci's mismanagement of the city's finances to great effect. Cianci sunk deeper in the polls with each new installment of bad news. On election day he was sunk for good, having never laid a glove on the Governor.

\section{VIII}

On election day the issues were decided. 403,765 voters

* A fact Ronald Glantz did not care to mention when he talked about Garrahy's wish to embarrass Cianci. 
trooped to the polls that day. ${ }^{26}$ Because every voting district is equipped with voting machines the results for all but the very close races were known before midnight.

Jimmy Carter won the state by a very comfortable margin of 43,000 votes. Garrahy humiliated Cianci 299,174 to 106,729a margin of three to one. Garrahy ran well behind must of the Republican ticket. He got only 17,000 more votes then the totally unknown Republican candidate for General Treasurer. 27

$77 \%$ of the registered voters had turned out. 28 They also gave a striking majority to the Narragansett Bay bond issue. It carried 215,614 to $103,069.29$ This two to one margin certainly constituted a mandate for change.

True, 85,000 didn't bother to vote one way or another on the bond issue. Even if all of them had voted no the bond issue would still have passed decisevely. Why did this happen with nary a word of dissent?

IX

The bond issue was certainly an"apple pie" question. It was difficult to oppose without looking like a supporter of dirty water. Two people as disparate in outlook as Trudy Coxe and Ronald Glantz both agreed that no politician "dared" oppose the bond issue. Both parties supported the state takeover, both in the legislature and the election campaign. If Mayor Cianci had any reservations he kept them to himself. 
With no major politicians or important organized groups opposing the bond issue it was difficult for any opposition which may have existed to coalesce. Since 103,000 voted against the bond issue (for whatever reason) there must have been some unhappy people out with some reasoned arguments against the idea.

Supporters of the bond issue had a rallying point, advertising support and the unstinting enthusiasm of the state's major newspaper (made quite clear once again just before election day). Any opponents had no rallying point. If they existed they remained diffuse and unorganized. This major issue recieved so much support from the state's "movers" that it became a non-issue. Any opposition was smothered in the great big pillow of an awesome consensus.

\section{$\mathrm{x}$}

With its thumping mandate the Bay Commission could procede to business. Trudy Coxe was typical when she thought the negotiations to transfer the plant were a virtual formality that could be accomplished in a few months. It was not to be. The Commission quickly became bogged down in a political problem entirely of its own making. After extricating itself from that mess the Commission had to deal with the city's obstrperous approach (and sometimes lackadaisacal approach) to the transfer negotiations. Occaisfurs ly Cianci's inattention was understandable. More often it was 
irritating. Almost always it was just plain baffling. As of March 1982 the city still had the plant with no firm transfer date in sight. Supporters of the Bay Commission are furious about this. Most people seem to have no' idea why this apparently simple task of transferring the plant from the city to the Commission is taking so long. That will be the subject of the next sections of this report. 


\section{Trouble Getting off the Ground}

Those who have read the work of Martha Derthick of Jeffrey Pressman and Aaron Wildavsky will not be surprised about what happened next. However, few if any of the actors in this little melodrama had ever read these minor sages; they shocked the transfer process was taking so long.

The pattern is becoming well known. Poltiticians rush through a brand new policy and program designed to save the day (and their jobs) with a plan on the statute book and an appropriation in the budget, the movers retire from the field. Sometimes they recieve progress reports directly; often their information on progress is second hand.

When the "stars" leave, as they inevitably must, the game is left to relative nobodies; obscure bureaucrats and interest group representatives who actually decide the shape of a program. In fact it is in their hands as to whether the victory that was won (with the passage of a new program) stays won.

With a famous victory won the Grand Coaliton broke up, its members going their separate ways. Mayor Cianci returned to City Hall; restoring his tarnished political career was his obvious priority. Governor Garrahy went back to the affairs of state. Gary Sasse turned to other projects. Mary Kilmarx left the legislature. The Journal found other editorial subjects. Trudy Coxe thought the most difficult 
part of the game was over.

Things started to return to normal. The regular contentious political process had been to a great extent overriden when the sewer bonds were presented and approved. Now the traditional way of doing things was reasserting itself with a vengeance. The Commission, just a few weeks into its work,got stuck in a poltiical controversy that came close to discrediting it.

One of the first items of business for the comm ission was to select legal counsel. The plant transfer negotiations had to be prepared for and conducted. There were a myriad of jobs, large and small, associated with this task. Commission Chairman Joseph Turco, appointed by Governor Garrahy, estimated there was enough work to keep three lawyers busy. 1

over thirty lawyers applied for the job. Only two were interviewed- the only two candidates who were deemed serious prospects for the job: Anthony Bucci, Chairman of the Providence Democratic City Committee and Louise Durfee.

On January 21, 1981 the Commission made its choice.

Bucci got six votes, Miss Durfee five. Charles Mansolillo, an appointee of Cianci's (and the rising man in the Cianci Administration) voted for a third candidate. This threw the vote to Bucci. All four legislators voted for Bucci, as did the appointees of the Mayors of $N$ orth Providence and Johnston? 
The howls of protest from environmental groups and the Providence Journal was immediate. Its vehemence was startling. One man's anger in particular gave the protest force : Governor J. Joseph Garrahy.

The Governor, not a man to seek confrontation, swore he would use any means to dump Bucci. ${ }^{3}$ He implied he would use his power to control Commission funds to deny Bucci his salarly. 4 Garrahy seemed to take the whole thing personally. The next day, with the television cameras rolling, he didn't bother to make implied threats. He stated them clearly:

" I'm going to make sure, if it takes years that that commission is going to be put in place properly before there is any expenditure of dollars by the state of Rhode Island." 5

He considered the whole thing a personal affront.

" I resent the intrusion and politicking that is going on on that Bay authority and I ' $m_{6}$ going to do everything I can to stop it."

It was an impressively angry performance by the Governor. Environmental groups led by save the Bay were also angry. Trudy Coxe said:

"We are urging you(state legislators) in the strongest possible manner to exert your influence and concern to correct the widespread impression that the representatives of the perple...will sit idly by and permit politics as usual to determine public policy on issues of enormous importance to the state." 7

The Journal needless to say, had some thoughts on the mat-' eer. The title of their editorial " Raw Sewage, Raw Politics" conveys the flavor of their dissent. 8 
It was pointed out that all of this might have been avoided had the Governor appointed his full compliment of members to the commissiin ${ }^{9}$ (one seat was vacant) In the heat of the moment this little fact was glossed over, though it does seem to show inattention on the part of Garrahy (or rather, his staff).

\section{$\mathrm{V}$}

The identities of the six commissioners who swung the vote to Bucci (two senators, two representatives and the men from North Providence and Johnston) made it plain to all but the green and the naive that some sort of Byzantine deal had been cut. Since all six had some connection to Rocco Quattrochi, it was not difficult to see the fine hand of the new Senate Majority Leader somewhere in this. 10 This left the questions: What was the deal? Who was it for?

The Providence Journal quoting the usual unnamed sources, reported it was a straight swap between Quattrocchi and Mayor Cianci. According to the Journal reporter, Cianci agreed to acquiesce in the selection of Bucci (once an enemy of Quattrocchi's, but now an ally in his efforts to reunify the badly divided Providence Democrats) ${ }^{11}$ in exchange for Assembly support for a bill that would validate the supplemental tax levy the city was imposing to stave off fiscal collapse.*

* The city was not sure the extra levy was legal. It sought a special act to preempt any court challenges. 
This story was widely believed at the time. No other explanation ever made the pages of the Journal.

A person in a position to know told another story. This person can not be identified, but the story told made Rocco Quattrocchi's supposed role in the published accounts seem almost altruistic in comparison.

According to this person it was indeed a straight swapbetween Rocco Quattrocchi and Anthony Bucci. The deal was mutually beneficial to both men. Bucci would become legal counsel (considered a "plum" job); in exchange Bucci would support Quattrocchi if he sought the Democratic Mayoral nomination in 1982. Between them they could probably control the City Committee's endorsement.*

It was a c lever plan. There was only one problem with it: Bucci's appointment had to be announced and explained. It was announced, but never really explained, at least not by the Commissioners who voted for Bucci. They contented themselves with counterattacks on their critics. Senator William Castor, a close associate of quattrocchi's said it was"a fight the Governor had already lost." 12 Not quite.

\section{VI}

The story has the ring of truth to it. Cianci's appointees did not vote for Bucci. The Mayor denied making any deals.

* The endorsement is the designation by the party organization of its favored candidate. Through the early 70's it usually guaranteed the nomination to the recipient. In 1982 the endorsement went to Francis Darigan, who had already lost bids for Mayor in 1974 and 1978. 
The Assembly leaders made it clear they would not pass a bill to validate the tax levy. Speaker Matthew Smith was imsistent upon that point. The Assembly in fact never did pass a bill to validate the extra tax. The leadership's position was that it was unneccessary. 13

VII

Rantings from the Providence Journal and ravings from Save the Bay do not sway too many hearts and minds on Smith Hill (location of the State House). Pressure from the Governor is another thing; and the Governor absolutely, positively insisted.

\section{VIII}

All of this made Rocco Quattrocchi eager to backtrack. The controversy he had stirred up obviously took him by surprise. 14 He and the Governor looked for a face 'saving way to ease Bucci out. (These talks tend to confirm that Quattrocchi was involved in this from the beginning) A formula was worked out soon enough.

It was simple. Bucci would keep the job, but would be unsalaried. The commission would retain a roster of lawyers; all of them would be eligible to do legal work for the Commission. Bucci would be one of these lawyers. He would be paid by the job.

If everybody wasn't happy at least the fuss was over with. A short time later a bill was rushed through giving the Gov- 
ernor four more seats on the Commission. He now controlled 16

a majority. After making the appointments he retired from the stage once again, his second extraordinary intervention over. He hasn't been publicly involved since. The state's own budget difficulties preoccupy him. Now the commission could begin its work. 


\section{On tine Back Burner}

With the Anthony Bucci incident behind it, the Bay Commission could now get going in earnest. Chairman Turco estimated the Bucci episode set the whole transfer process timetable back sixty days. ${ }^{1}$ That may have been true, but in the end the Bucci holdup didn't really matter. Everything soon got so snarled that the events of January became half forgotten ancient history.

\section{I}

The city and the Bay Commission staffs prepared their respective bargaining positions. ${ }^{2}$ It was hoped the plant could be transfered by september. While this was going on the Bay Commission set about hiring a staff. The first person hired was the first permanent Executive Director.

The Commission chose Eric Jankel. Jankel was originally a staff member for Governor Garrahy's predecessor, Philip Noel* When Garrahy became Governor in 1977 Jankel stayed on. Eventually he became head of the Governor's policy office.

Jankel left to enter private business. He didn't stay there long; he left to become a top aide to secretary of the Interior Cecil Andrus. When the Carter Administration went under Jankel became available. He took over at the Bay Commission in the late spring of 1981.

* This writer did an internship in Governor Noel's office in 1975. Occasionally I worked for Mr. Jankel. 
As a young "old pro" with credibility to both Democratic politicians and interest groups, Jankel seemed an excellent choice for the job.

\section{III}

Now the story must digress a bit into providence politics. Events in the capital city were to slow things up considerably...

Things were not good over at City Hall. In the spring of 1981 the entire city administration seemed to come unglued. There was instabilty at the top. With the city going broke there was no permanent Finance Director. With city services under dispute the Public Works Director was under public attack by the Mayor himself (and soon fired). Ronald Glantz left the city's employ to go into private legal practice. Glantz was replaced by the elusive Charles Mansolillo.*

Things were so bad there were rumors (but never more) that the Mayor himself was thinking of fleeing to a post in the new Reagan Administration. Cianci denied these reports. When he did so he left few in doubt he would seek a third term in 1982. This meant 1981 would be spent laying the ground work for that crucial poll.

Providence's budget problems finally became the bona fide crisis newspapers like to headline. Missed payrolls loomed.

* Mansolillo is a low keyed political chameleon.originally elected as a Democratic Councilman he still serves on that body. He has since called himself an independent and filed for reelection in 1982 as both a Democrat and independent, before finnlly running as a Democrat. The Mayor pays his chief of staff out of private campaign funds. 
The city wasn't paying its bills. There was little cash on hand. Municipal bankruptcy seemed a real possibility. (Some of the city's less responsible Democrats actually urged this) The banks were reluctant to make the usual short term loans the city needed to tide itself over.

The Mayor of course couldn't let the city go under. It would surely end.his political career. Bowing to reality the Mayor let the banks call the shots.

The Providence Review Commission was established in the late winter of 1981.* It took over direction of the city's finances. One of the things it recommended was a supplemental tax levy (already mentioned) to get the budget in order. The banks made passage of this extra tax a condition required before they would grant additonal short term loans.

The Council, with a gun to its heads, passed the supplemental tax, but the public was livid. The council had no choice since it was a non-negotiable demand of the bankers.

It is no wonder the transfer negotiations were not a priority of Cianci's. Robert Chase, the Mayor's aide, confirms this. By the time the financial situation was put into some kind of equilibrium trouble broke out on another front.

\section{IV}

The Mayor had had a history over the last few years of problems with the city employees' union. In 1981 quiet hos-

* The Commisson consisted of prominent local businessmen, bankers and civic leaders. One of the members was Gary Sasse, who certainly gets around. 
tility broke into open conflict. There were two city employee strikes. The second strike, which started in late July, turned out to be a total disaster for the union and a political triumph for the Mayor. All the city's garbage collectors were fired; the union had to swallow it. Trash collection would be done by a private firm in the future. This meant the city was out of the garbage business. This was to affect negotiations with the Bay Commission, though few noticed at the time.

$\mathrm{V}$

Over at 57 Eddy Street (just behind City Hall), where the Bay Commission had set up business, all of this was watched with interest. After an early "intense start" 4 negotiations had been in limbo for weeks. The Bay commission could not seem to interest the city in serious talks.

On June 28, 1981 the Bay Commission sent over a first draft agreement to the city. ${ }^{5}$ It was now plain that sometime in autumn was the earliest possible transfer date; late autumn at that for the city did nothing about the agreement for weeks at a time. 6

This apparent indiffernece on the city's part baffled Eric Jankel. 7 It seemed to him in the city's interest to transfer the sewage system to the Bay Commission and get it off the municipal budget as quickly as possible. 8

If Janlel was baffled, many were angry. Environmental groups couldn't understand the hold up. Neither could the press, when it cared to comment. 
This time there were no interventions by anyone. The process would run its normal course. 


\section{The Negotiations}

July 20, 1981 was notable for two reasons; it was the first day of the second city employees strike; it was also the first time in a long time the city and the Bay Commission had sat down to talk. The topic: the draft agreemey sent over to the city on June 28 .

Eric Jankel was not happy with the meeting. It was clear to him the draft agreement "hadn't been read" by the city's negotiators.

The strike put the talks on the city's most remote back burner. ${ }^{1}$ This was perhaps understandable.Yet once the strike was settled (in early August) the city still did not appear eager to get back to the table. ${ }^{2}$ According to Eric Jankel this was not due to any lack of effort on the commission's part.

In August Jankel gave a presentation to the Providence Review Commission. He gave the group a projection of the savings the city could realize by getting rid of the plant quickly.* Jankel was dismayed because he thought the whole issue "didn't seem important" to the city's officials. By the time the talks resumed ("around Labor Day") ${ }^{3}$ it was plain the newest transfer deadine (November 1) wouldn't be met either.

* As much as $\$ 3$ million in Fiscal Year 1982, according to Jankel 
The distance between the Bay Commission's offices and those of Mayor Cianci are less than a few hundred feet. In terms of the progress made toward a transfer date the distance might have been as wide as the Grand Canyon. Progress would be reported during negotiations, but nothing seemed to be happening. Critics of the city found Mayor Cianci's public comments irritating.* This is not important. Cianci was employing traditional bargaining stances. What was important was the citys consistent lack of interest in winding up the negotiations quickly and getting rid of the plant. The Mayor sometimes appeared to be deliberately prolonging the process. A couple of months after the negotiations finally concluded Jankel was still visibly (if politely) annoyed with Vincent Cianci, He thought the Mayor's style"conflicted with the public interest". ${ }^{\mathrm{a}-}$

Jankel was critical of the city right down the line. He thought the Mayor's demands "posturing". (Robert Chase admitted this was true, but obviously didn't understand what the fuss was about) and thought the city was often not prepared to taik seriously. Cianci did a lot of the negotiating hinself, face to face with Chairman Turco. Jankel was very critical of this. He thought Cianci should have left the

* In public the Mayor consistently demanded a cash payment for the sewage system. An obvious bargaining ploy since Cianci, a lawyer, well knew a cash payment was forbidden by the Bay Commission's enabling act. 
job of hammering out an agreement to his staff. Jankel thought Cianci's insistence on involving himself in everything smacked of "government by Czar". ${ }^{5}$ He also denied the charges of footdragging aimed at the Commission by Robert Chase.

III

Robert Chase is the City Historian and Executive Director of the Providence Heritage Commission. Ronald Glantz drafted him for "sewer duty". When Glantz left the city, Charles Mansolillo asked Chase to continues to be the staff member responsible for this area. Chase, naturally, defends the city's conduct of the negotiations. He does not think the city's side of the talks was understood. He stated that the city's public stance was misrepresented.

According to Chase the city was simply trying to get the best deal for itself- as was the Bay Commission. The negotiations were difficult for the Commission was as determined to get its way as the city.

Chase concedes the city's original demands were "outrageous" - as were the Bay Commission's. (According to Chase the Bay Commission's first draft allowed them to demand any city property it wanted "including City Hall") ${ }^{6}$. He stated that environmental groups and newspapers which were critical of the pace of the talks did not or would not understand the nature of difficult negotiations.*

* Trudy coxe in particular drew Chase's ire. In the Warwick Beacon of september 29, 198? Miss Coxe was quoted describing the talks as "ridiculou:ky slow" and suggested the city might be"deliberately negotiating in bad faith". 
Chase believes the Commission dawdled. They took until June 28 to send their first draft agreement over to the city. He made much of this, since the Bay Commission was not distracted by budget problems and strikes.

Chase wasn't directly asked, but he would no doubt deny the city talked in bad faith. (when asked this question about whether the city negotiated in good faith Jankel said, "sometimes yes, sometimes no.") 7

It was suggested by one well place individual that the Mayor was recieving some remarkable advice: keep the plant, charge user fees and take on the rehabilitation project itself. In effect, tell the Bay Commission to "get lost". Chase denied this. He said there was no question the city would eventually transfer the plant. If the Mayor did revieve this advice and then taken it the result would have been very interesting.

Negotiations were"intense" 8 in October and November of 1981. An unsigned, undated memo from the early $p$ arts of the talks listed what were to be the three main issues of the talks. (1) What compensation would the city get for giving up its system? (2) What to do about the plant's incinerator, which did not meet EPA's clean air standards? and (3) What about the Inge co. contract, a recently signed deal for the disposal of the city's trash and sludge? Compensation was settled amicably enough, after pro- 
tracted haggling. The Commission would assume $86.4 \%$ of the city's outstanding debt for Sewer Bonds issued in september 1980 . This came to around $\$ 7$ million. ${ }^{10}$ The Commission also assumed $\$ 4$ million worth of bond anticipation notes issued pursuant to another bond issue. 11 AItogether the Commission agreed to assume over \$ll million worth of the city's bonded debt. 12

The incinerator was to be in compliance with EPA regulations before the Commission would take title to the plant. However, if the plant was not in!compliance and this was the only obstacle to a transfer this requirement could be waived. 13

The Commission would not pick up the Inge co. contract. ${ }^{14}$ By this time the Inge contract had become the major block to a transfer. It derailed the whole timetable one more time. What was all the fuss about?

\section{$\mathrm{V}$}

On June 6, 1980 the city, acting with the approval of the Board of Contract and Supply, approved a contract with the Inge Co. At the time at recieved no attention. The agreement called for the city to, over its trash and sludge to Inge for reprocessing into fertilizer or heating fuel. 15 By the contract Inge would charge the city $\$ 25$ a ton for removal of its sludge, with a minimum guarantee of $\$ 2,500$ a day. 16

The contract appeared to make sense for the city when $\therefore \therefore$ 
it could supply both refuse and sludge. ${ }^{17}$ It was a bad deal for the Commission, for that agency dealt only in sludge. ${ }^{18}$ An inflation escalator clause in the contract, which ran for ten years, could raise the annual payments to Inge from $\$ 1.1$ million to over $\$ 7$ million. ${ }^{19}$ Eventually the Bay Commission, spoken for by Eric Jankel, made it plain the contract would not be picked up.

The financial aspects of the contract were not the only criticism. A consultant to the Rhode Island Solid waste Management Corp. said a heavy lead content in the final product produced by Inge could contaminate crops and groundwater. 20

Inge Co. is controlled by James Notorantonio. He made sure it was known his contract was going to be picked up or there would be expensive litigation to pay.

Two important questions emerged: Who was Jim Notorantonio? How did this contract come about? Everyone around the water Pollution Program wanted to know, yet no answers were forthcoming. This writer's researches uncovered no answers. Notorantonio is not a public figure; neither he nor anyone else connected with the city chose to explain the hows and whys of the contract.* In lieu of answers to these questions there was still another one to answer. Who was going to "eat" the Inge contract ? The City? The Bay Commission? Or

* A Superior court deposition James Notorantonio gave when he sued to block the transfer of the plant was very uninformative about these questions. He obviously didn't care to talk. 
James Notorantonio?

The contracticalled for its obligations to be passed onto the city's "successors and assignees". But the Bay Commission's charter gave it the power to pick up the city's contracts relating to the sewage system at its own discretion. It was clear the Commission wanted no part of Inge Co.

Eric Jankel was very critical of the contract at several public hearings.He wanted no part of it in its present form. He wouldn't budge from this position.

In a complaint filed in superior Court, Inge Co. summed up its arguments: The contract was binding. Inge depended upon it to amortize its debt. Without the money from the city Inge would surely fail. 21

Jankel was not very sympathetic to these arguments. He noted other city vendors were going through the sane uncertainties bothering Inge Co. No one had any guarantee the Bay Commission would want their services. Inge was just one of the pack. "Private enterprize has a right to fail ", he said.

VII

James Notorantonio finally emerged to talk about the problem. An entire meeting of the Providence Water Pollution Abatement Program Citizen's Advisory Committee was devoted to the issue. The meeting was very well attended. Notorantonio was all sweet reasonableness. He told the 
meeting he was willing to compromise. He was ready to sit down and talk things over. He didn't want to prolong this lenghthy transfer process any furthur.

Whether Notorant onio was sincere is not known. One thing is known. The City and Bay Commission did reach agreement. The Bay Commission would not pick up the Inge contract. What to do about it was the city's problem.

\section{VIII}

The city's problem was considerable. As of July it was out of the trash collecting business. When the commission took over the plant it would be out of the sludge business as well. If the city were to be held to the contract it would have to pay $\$ 2,500$ a day to deliver sludge and trash it didn't have. At $\$ 1.1$ million a year it added up to a neat little welfare program for Inge Co.

\section{IX}

The talks proceded apace. By November 1981 the major points had been decided, according to reports delivered by both Chase and Jankel to the Citizens Advisory Committee. All that remained was detail work. Finally an agreement was hammered out.

On December 16, 1981 Mayor Cianci and Chairman Turco signed the agreement in principle. It encompassed the main issues plus many others that were not controversial. It required the city to adopt a system of mandatory user fees 
before the Commission took title. A closing date of February 26,1982 was set. The ceremony would take place in the Mayor's office. The closing date could be put off until April 1, 1982. After that the agreement was off. ${ }^{23}$ Both sides gave some. The city got a large amount of its bonded debt taken off its hands, plus a four million dollar a year expenditure for plant operations. The Commission decided not to take a hardline position on getting the incinerator in good working order before taking title. The city allowed the Commission to walk away from the Inge contract. While not part of the formal contract it became clear the Bay Commission would help the city out a bit when it tried to walk away from the contract too.* Everybody seemed happy with the agreement.

$\mathrm{X}$

With the agreement signed the end seemed in sight. There was little criticism of the agreement. Trudy Coxe was one of the few who were less then pleased with it. She was still upset about the time it took. She was unhappy with the "pol-" itical game" played by both Jankel and cianci.

She thought the Commission had ducked the issues. Miss Coxe thought the agreement should have covered future staffing. (Jankel said the Commission wouldn't get involved with staff issues until it took over the plant) ${ }^{24}$ she also thought

* When Inge took the city to court to block the transfer of the plant in February 1982 the Bay Commission involved itself in the suit even though it wasn't a party. 
a final settlement of the Inge contract should have been worked out. ( Jankel said, as far as the Bay Commission was concerned it was finally settled $)^{25}$ she predicted the whole dispute would end up in court. (it did); this prospect of more delay made her very unhappy. 26

\section{$X I$}

Trudy coxe never went public with her complaints. No one else was publicly critical. It remained to be seen whether or not the latest deadline would be met. It soon became clear it was not going to be. 
By and for Whom, or, where were the People?

In a democracy like Rhode Island's all actions of the state are by "the people", working through their elected representatives for "the peoples" welfare. Even the most blatant special interest legislation is justified by someone as being in the public interest. The controversy surrounding the sewer system in Providence was no exception. Unlike most issues the public had actually spoken. No matter which way the 1980 Narragansett Bay Sewer Bond issue is interpreted, it was a powerful mandate to preserve a treasured natural resource. The voters made this wish emphatic when they committed $\$ 87.7$ million of their money to that end.

Except for one short day at the polls the "people" have been conspicuous in this story by their abscence. Why was this? Were their opportunities for the "people" to get involved? Would they have been Iistened to when they showed up ?

\section{II}

There was a public participation program. In 1980 the city was in the design phase of Phase II of the facilities plan. (This was going on under the city's auspices because the city still owned the plant. In mid 1980 a state takeover was still not certain):i.e., what kind of hardware was going into the refurbished plant? ${ }^{l}$ Federal regulations required the city to appoint a Citizens Advisory Committee ( $C A C$ ) to 
advise the project managers, Charles J. Krasnoff and Associates, (CKA) and the various engineering firms who had the contracts to evaluate and design various aspects of Phase II. ${ }^{2}$ Universal Engineering, of Boston, was designing what would be for all practical purposes a new plant. Castellucci, Galli, Hayden, Harding and Buchanan were doing work on CSO 9. C.E. Maquire (CEM) was doing preliminary work for CSO 2. The record of the CAC advising these engineers was spotty. Domenic Tutella, Universal's man on the spot, usually smiled at advice and ignored it; Paul Sylvia of Castellucci, Galli made efforts to explain what his firm was trying to accomplish. He also tried hard to sell the CAC on building CSO 9 every chance he got. (since there was no guarantee it would be part of the final plans); David Wescott, of CEM, apparently listened as well as he explained. (which was very clearly) $\mathrm{His}$ firm was to come with recommendations regarding cSO 2 which were so simple and inexpensive that some listeners were stunned. But that is running too far ahead of the story.

\section{III}

The original CAC was appointed during the summer of 1980.* It held its first meeting in the offices of Charles J. Krasnoff; thereafter it moved tp its semi-permanent home in the committee rooms of the State House. At 29 members it was one

* This writer was tenatively asked to if he was interested in serving on the CAC. This didn't happen, but the events it set off led directly to this project. 
of the largest such committees ever set up in the entire country. ${ }^{2}$ This size was in recognition of the magnitude of the Providence situation.

The CAC was a piebald group of politicians, interest groups and members of the public. During the time the CAC was the city's responsibility (October 1980 to March 1982) the Chairman was Dennis Nixon, a person wearing many hats as a URI professor and lawyer for the shellfishermen. The firm of CKA got the public participation contract. They provided staffing, coordinated by Ezra Schneider. Some CAC "public outreach" work was subcontracted to a consultant. The CAC was also fortunate to have the volunteer services of a URI marine scientist, Dr. Eva Hoffman. She was often a useful counterfoil to the engineers; she reminded the CAC that when it came to pollution of the Bay answers were being given when very little was known about the total situation.

Some of the politicians on the ICAC were high powered or ambitous. Victoria Lederberg, a leader of the state Democratic Party and state representative from the East Side, was an original mamber*. So was steven Fortunato, a state senator just off an unsuccessful primary fight for Congress. Charles Mansolillo was a member. He was not yet the Mayor's top aide, but he was a prominent supporter of the Mayor on the City Council. Several lesser political lights also served. The

* In 1982 Mrs. Lederberg is the Democratic nominee for Secretary of State. 
rule of thumb appeared to be: the bigger the pol, the quicker the exit. One politician, a member of the North Providence City Council lasted almost a year; most were gone in a few weeks, if not immediately (as was the case with Lederberg) *. No politician lasted the distance. Why is not known; perhaps it was because the CAC represented a major committment if taken seriously, with no prospect of a useful poltical payoff. Disputes over sewers are not glamor issues.

The ordinary citizens showed less tenacity then the politicians. There were some notable exceptions, however. Miss Anna Louise Nestman, a very sharp old lady, longtime environmentalist and League of Woman Voters activist attended all the meetings and made her presence felt. She persistently asked the question no one seemed eager to answer. It boiled down to: "We have an idea what we need; now what can we afford and get an acceptable job done?" John Kellam, already mentioned, came to CAC meetings as an interested observer; when a vacancy occurred Mayor Cianci appointed him to fill it. He remained active with the CAC after his retirement from the city early during the winter of 1982 .

Russell Chataneuf, an engineer with the state Department of Transportation, also stayed with the CAC the entire time. He appeared to take the exercise very seriously. Another private citizen, Mrs. Deryl Johnson, also was fairly active. Predictably enough, the interst groups showed the most

* In the case of Fortunato one observer said, " Fortunato pounded the table for a couple of meetings, saw no one in the press paid any attention, and quit." 
staying power. Attending meetings was part of their jobs. Trudy Coxe and David Strouss were members, as was Edward Zesk, of the Rhode Island Hospital Association, and Dennis Nixon. Other groups sent people, if not always the same ones. Robert Chase was considered Mayor Cianci's personal emissary to the CAC. He usually smoked his pipe and said as little as possible. (a wise strategy for an emissary of any kind)

IV

A year after it was set up Chairman Dennis Nixon had a pretty negative view of the CAC. He thought it had"no impact" and the participation was "illusory"; on the other hand he noted the CAC did bring all parties together at least once a month. The dislikes and turf disputes came out into the open. Nixon thought it was important for people to see and know that "Chino (K.N.Srinivasa, CKA project manager) and Dom (Tutella, of Universal Engineering, the head designer of the rebuilt plant) hate each other's guts."

Nixon thought the CAC acted as a good forum for state agencies to float trial balloons. The CAC "acts as a fall guy." Nixon thought it was a useful, job for the CAC to do, if not always a pleasant one. Over all this was not a happy view of the CAC's pertormance.

Nixon was very unhappy with the media coverage CAC activities had recieved. For this be blamed the "inept nature of the contractor", CKA. - Ft. it: 
Nixon's unhappiness with the virtual privacy in which CAC business was conducted was not unique. Ezra Schneider, CKA's Coordinator of the Committee was also unhappy; so for that matter was Eric Jankel. CKA did have its problems, but to blame the staff there for the blackout is unfair.

\section{$\mathrm{V}$}

Two newspapers covered CAC activiites: The Warwick Beacon sent John Monahan, who usually attended. The Providence Journal sent a succession of people. ( the most recent Journal reporter on the beat cheerfully admitted his near total ignorance of the issues at hand to Ezra Schneider) Radio reporters showed up on occassion. Television crews were the most rare. This writer never heard any of the radio coverage. The television reports were uniformly bad. The typical casual viewer could glean little of value from them. There was no way these issues lent them selves to the usual format of a local news program.

This left the newspapers. The Beacon as already noted, usually sent Monahan. If he did come a report of the CAC meeting or activity would usually appear in the next issue. Monahan's stories were reasonable efforts, considering he worked for a small newspaper and had other beats to cover. The Beacon, a modest effort which is published twice a week, obviously devoted a larger percentage of its resources to the story then did the mighty Journal. Warwick is a West 
Bay community much affected by the sewage problems of Providence. This makes the Beacon's interest natural. The paper is little read outside of warwick, however.

This left the Providence Journal; its coverage was not consistent. It was rare a week went by without some Bay related story making its way into the paper. But the coverage was not especially informative. Stories regarding political skullduggery (Anthony Bucci), legal disputes (Inge) and trivia (Eric Jankel's pension plan) were all covered and recieved good play. Complex stories like the transfer negotiations or the bureaucratic fight the spend the $\$ 87.7$ million bond issue are covered shallowly, if at all.

Ezra Scneider, of CKA, made several attempts to persuade the Journal that the CAC was a usueful, interesting forum where some very important issues were being discusses. The Journal must not have been impressed by these arguments, for there was no regular coverage of the CAC. This is unfortunate, for their editorial writers will almost surely scream loud if the rebuilt plant gives disappointing results.

\section{VII}

The obscurity of the CAC was too bad. The irony was a citizen desiring information could get it readily at CAC meetings or meet someone there who could find out for them.* A particularly inquisitive citizen could easily become

* As one participant said, "All the people in the world who really care about sewers in Providence are in this (the CAC's ) meeting room- all twenty of them !" 
as did this writer, a sort of pseudo-insider. That is: well informed and trying just to observe, but influencing events just by being there. ( A classic social science problem known as the Hawthorne Effect).

This is not to say the public would have had a lot of influence. (unless they turned out in force, which was very unlikely) "Professionals" like to control their own games; they actively resent and obstruct intrusions by "laymen" into their activities. Engineers are as prone to this as any group. This meant the interested citizen was heard but often not listened to. In this writer's view, Universal Engineer was the worst"listener", C.E. Maguire the best.

The engineers usually attended the public meetings and hearings of the CAC. Sometimes a presentation would be interesting (usually CEM's); more often they were dull, with lapses into the imcomprehensible. The Washington Park public hearing in April 1981 was the ultimate in pro forma events that were by anybody's standard a waste of time, save those with a perverse sense of humor.

At Washington Park the subject matter was the new plant and CSO 9. Both would be located near the vicinity, a formerly solid working class area now showing the first signs of urban decay. The hearing was held in conjunction with a regular meeting of the Washington Park Community Association. There was a fairly well attended Association meeting, a raffle and then a presentation by the engineers. Unfortu- 
nately the raffle took place before the CAC hearing; after it was over most of the locals bolted, impervious to the pleas of CAC staff and others for them to stay. The meeting was left to CAC members and staff, engineers and few groups of old women there to socialize till the hall closed. A few younger residents of the neighborhood stayed out of curiousity.

This writer saw few sights more ludicrous that year then Domenic Tutella making his presentation ( which was too technical for casual observers) to a small crowd of happily gossiping grey haired old ladies and a few thouroughly confused locals. Tutella made little effort to produce a talk understandable to an intelligent layman.

The low point (or, depending on your point of view, the high point) of the evening was reached when Tutella and another engineer literally nearly came to blows over a matter of "professional disagreement".*

More typical of CAC activities was the hearing held in the handsome, new opportunities Industrialization Center (OIC) building in South Providence, the city's most decayed area. The CAC hearing, a full blown affair with a stenographer, was the only activity planned. The CAC and its hangers on could have put up two football teams; memsbers of the public would have trouble mustering five people for a basketball game. while the necessary business on the stage

* I never learned exactly what the near fight was all about. Tutella apparently thought the other engineer had made a public attack on his competence. 
droned on, the regulars at these meetings drifted in and out, getting coffee and gossipping in the lobby. They resembled nothing less than a typical meeting of a state legislature.

The best meeting (in terms of informitiveness; it was, like the rest, poorly attended) was held in the auditorium of Women's and Infant's Hospital, in the Smith Hill-Davis Park section of town. Here the topic of discussion was CSO 2 .

C.E. Maguire was studying this problem. Their team gave an interesting and effective presentation in which they defined the problem they were going to examine (how the sewers in their study area really worked and how much water actually flowed through them), their methodology, and how they would use their data base to reach conclusions. They had the job of recommending whether or not cso 2 was a priority. The Maguire show was so good it was repeated several times by popular demand.

\section{VIII}

Most civil engineering questions can be described in a manner understandable to"laymen". This allows for an intelligent decision, provided the explainer is trusted. In the case of Domenic Tutella, the designer of the rebuilt plant, trust or competence was not an issue. He simply was not responsive to criticism, especially if it came from 


\section{a non-engineer*}

There was an $\$ 87.7$ million bond issue; Tutella brought in a design for an $\$ 85$ million plant. ${ }^{4} \mathrm{CAC}$ members and others questioned the wisdom of this, considering the uncertainties about inflation and the availability of federal funds. Miss Nestman often questioned whether the city could afford the "Cadillac" Tutella was designing.

Other people, engineers with CKA, were mindful of the CAC's comments. As a result they were making efforts to hold down the cost of the new construction. ${ }^{5}$ For a while it did seem as though millions were going to shaved off the design. Tutella, though, had a way of letting the cost of his plan creep back up. It is uncertain just what price tag the final design will carry.

Miss Nestman persisted. She wanted a cost effectiveness study done of some aspects of rutella's plans. For $\$ 35,000$ Tutella himself would do the study- a sham procedure, since he had already decuded to stick with his original design. $7 *$ *

* As one person said, "Dom will smile for awhile, then pull out the knife."

** To stick with the "Cadillac" analogy, Tutella wanted to build a facility that was "loaded". It would have all kinds of extra capacity it would never need(in the judgement of some CKA staff). Some believed Tutella was overdesigning the plant to protect his reputation.

*** At the last CAC meeting in March 1982 Miss Nestman asked when the Mayor would sign the order releasing the funds for Tutella's study. Appearing at the meeting later that night the Mayor told Miss Nestman (and everyone else) he had just signed it. Two weeks later it was still unsigned. As one observer said,"He probably can't find it." 
C.E.Maguire spent months studying the sewers of their district. It covered a good deal of the Providence length of the Woonosquatucket River. They gave regular, clear reports about what they were doing. They seemed to be attentive to members of the public who did speak up and members of the CAC.

Their recommendations were startling: Don't build cso 2 . According to their researches there wasn't enough storm water running into the system for the Cso to work; it would be hydraulicly impossible. Caution was urged when it came time to clean clogged drains and catch basins. They had been plugged for so long clearing them would, in effect, create a new system that would operate in new, unexpected ways. The results might not be desirable.

Maguire's team thought increasing the hydraulic capacity of the existing system and plugging up the numerous sewage overflows into the river would achieve very desirable results at a much lower cost then building CSO 2 .

Some were taken aback by this recommendation. Bay Commission staff in particular were surprised by it. Possibly people accustomed to dealing with sewage problems whose solutions called for huge expenditures of cash could not readily deal with a proposal that was both modest and inexpensive. 
The CAC did get some things accomplished. They used their little influence with the city to institute a program to fix the tidal gates*. They also brought some needed attention to a 14 million gallon a day dry weather raw sewage overflow. This turned out to be one of the more interesting sub-issues of the CAC.

The overflow resulted when a long length of sewer main finally became hopelessly clogged. The sewage couldn't reach the plant; it overflowed into the providence River instead. For less than half a million dollars a "diversionary structure" could be built which would bypass the clogged line and send the sewage to the plant for treatment.

Eva Hoffman strongly recommended this be done. She pointed out it would remove a major source of pollution no matter what. The improvement in water quality could be quite significant.

CAC pressure finally got the city to show some interest in building this small project. It may actually get done.

$$
\mathrm{XI}
$$

On March 10, 1982 the CAC held its last meeting as an organ of the city of Providence. Its federal money had

* Tidal gates are just that, gates which close during high tide to prevent salt water infiltration into the system. Over the years the tide gates had been allowed to deteriorate to ineffectiveness. 
run out. The meeting was held in the beautifully restored Aldermen's Chamber in City Hall. The Mayor himself gave it a sendoff. He did not seem sorry to see it go. The CAC had only been sporadically influential. The smaller the issue, the more likely the CAC could directly bring pressure to bear and get results. The city, led by the much maligned Cianci, actually made some honest efforts to respond to CAC requests. (as in the matter of the tide gates).

The engineers designing the various parts of the rebuilt system listened to the CAC according to their temperments. Here the CAC was in a frustrating situation. They were heard by people. According to one person who knew, some serious back room fighting went on over what sort of hardware would go into the new plant. There were people trying to hold down the costs and they were responding in part to what they heard at CAC meetings. Even if CAC could know this they couldn't see it. To all public appearances they were just another powerless "talking shop". The engineers meanwhile, were culivating the people who will actually be making the decisions: the Bay Commission and its staff. After eighteen months the CAC was reduced in numbers to interest group representatives, city officials and a few citizens. The CAC was operating in an information fog and knew it. Trudy coxe often complained that more study of the actual sources of Bay pollution was needed. She said that important decesions were being taken that were essen- 
tially leaps in the dark. At least one regular participant, originally not very sympathetic to this view, came around to agree with Miss Coxe. The misgivings of Trudy Coxe did not gather too much support- at least among the people actually creating the future program.

The CAC was always doomed to a large measure of frustration. Popular interest in designing sewage treatment systems is just about nil.( Until the bill comes in) The issues were never well publicized. Even if they had been the result would have not been immediately intelligible to the man on the street.

For all the money spent on the CAC* they never had a real staff all its own to develop and defend poisitions on the issues. To date this had meant no unified, specific stands on the major issues. It is impossible for busy people, meeting on the run, to hammer out credible positions on the issues.

\section{XII}

For all its failings the CAC served a useful purpose. It kept the game a lot more honest than it might have been had there been no one watching. For all of Dennis Nixin's unhappiness there was the chance for anyone to get involved. The CAC had no power to speak of; but it did have influence. The process may have been private (because the news outlets ignored its activities) but it was never closed or hidden.

* Over $\$ 150,000$ according to CKA 
The CAC helped insure that accessibility (unused as it was) and if it did only that the effort was worth it. As Ronald Glantz said, the people only care about sewers "when they flush their toilets and nothing happens." He is absolutely right. In the case of the CAC the public interest was looked after better than the people cared or, in truth, probably deserved. 


\section{The Endgame: Transfered at Last}

Trudy Coxe's prediction came true. Inge sued the city in early February to block the transfer of the plant. In keeping with the brief tradition of the Bay Commission, the February 26, 1982 closing cate was missed.

It took a month for the case to be heard and decided in Superior Court. In order to speed things up the Bay Commission entered the case on behalf of the city.

On March 16, 1982 Judge Corrine Grande issued her decision. She rejected Inge Co.'s contention the transfer would cause it great harm. There was no proof of that, the judge decided. This program was too important to the people of Rhode Island to be delayed any furthur. Her temporary injunction to block the sale was lifted; their were no judicial blocks to the transfer.

One more obstacle remained before the transfer could be made. The City Council had to assess mandatory user fees against users of the system, arrange for collection of the fees and turn them over to the Bay Commission.

The city balked and Mayor Cianci was the chief balker. He called the proposed fees "excessive" and made loud threats to veto an ordinance that was not to his liking. Meanwhile, the April 1, 1982 deadline came and went. The Commission, not wanting to call things off when they were so close to finally taking over, gave the city until May 1 
to implement the fees.

It seemed plain the Mayor was poised on the verge of making the user fees a campaign issue. He was in a tough three way race * for reelection and could use any weapon that came to hand. But in the end he didn't.

Why he backed down is not known. What is known is that a fee shedule acceptable to him was devised. He set out to use his considerable local clout to pass it. He was helped in this when some leaders of last year's unsuccessful tax revolt endorsed the user fees. (Mrs. Rikki Sweeney is by no means an East Side type, thereby discrediting Chase's contention no one outside the city's "silk stocking" district cared about the sewers) The Mayor was helped when the Governor quietly made some phone calls himself the persuade (or pressure) recalcitrant City Council Democtats.

It was close to the deadline when the Council finally acted. A few days before May 1 the Council gave final passage to the user fee ordinance. The margin for passage wasn't even close at the end. The council had come under enormous pressure in the end to pass the ordinance.**

On May 1, 1982 the Bay Commission formally took title to the Providence semage treatment plant at Field's Point. It was the commission's problem now, for better or worse.

* Cianci actually lost, or rather conceded, the Republican nomination to East Sider-. Ered Lippit, the House Minority leader. He chose to ran again as an Independent. The Democrat will be decided in a september primary. It is a-tribatéctotedaci that no onesounts him out.

** According to a State House source who needs to remain anonymous. 
With the commission in charge the plant has not been in the news; the ... user fees have been controversial. Johnston and North Providence are not happy with the fees and are refusing to pay. The road ahead for the Bay Commission is very rocky still; its job is unenviable.

\section{III}

Ronald Glantz has called the whole thing a joke from start to finish. If he is right, who was laughing? And at whose expense? 
Conclusive Conclusions

When the events of the last few years are examined in detail it should come as now surprize that the Commission has gotten off to such a poor start. The active proponents of a regional commission, in their eagerness to take advantage of the 1979 breakdown at Field's point, darted around the usuual obstacle course new state policies and programs have to negotiate. The flaw in the Grand Coalition was soon revealed: support for the Bay Commission was impressively wide, but it was not (with the exception of environmental) groups) very deep.

When the "crisis" passed the real mover behind the Bay Commission, the Governor, moved unto other things. This had to happen in any event. This left the matter in the hands of unknown bureaucrats, interest groups and the eity of Providence.

The other mover, the Providence Journal, still covers the Bay Commission. But like the Governor, other things have moved to the forefront of their editorial agenda. There were still editorials denouncing footdragging and the general slow pace of progress towards a state takeover; but with no dramatic issue to give their position some power they had little effect. Mayor Cianci and his men were certainly in no mood to respond to "ProJo" pressure in 1981 and 1982 .

The environmental groups are loud and their committment 
was deep. They were heavily involved in the decision making process. But their own influence was not enough to force politicians to act.

"Normalcy" returned to this iron triangle. The Bay Commission, brought into existence by the politics of the unvari: had to deal with "politics as usual" when the dust cleared. This was brilliantly symbolized by the Bucci episode, which was Rhode Island politics at its most depressing usual. Politics as usual occurred at a more mundane level as well. Relations between the city and state were terrible from the beginning and remained so throughout. Both sides were exasperated and mistrustful with each other. Most of the public exchanges were civil; in private the antagonism was evident to this observer. It did not make it easy for the city and state to cooperate.

\section{I}

The city had cause for complaint; this does not excuse some of the city's behavior. They were, on occassion, victims of shabby treatment; the city has never gotten proper credit for getting the plant running surprizingly well.

Yet it seemed to this observer the Mayor deliberately prolonged things into the election year. What was motivating the Mayor to be so uncooperative is unknown. He never went public with what he hoped to gain by all the confusion that surrounded the lengthy transfer talks. 
A lot of this could have been avoided by including the city in a positive way from the beginning. The Governor's failure (reluctance?) to consult the Mayor (a notably prickly character, sensitive to slights) was an inexcusable lapse of good political judgement and even good manners. The task force should have been a joint city state venture. Some speed may have been sacrificed, but what of it? For all the speed the Bay Commission built up in 1980 it did so only to hit the unavoidable muck of everyday politics at a greater speed. Possibly this got the Bay Commission bogged down even worse than it might normally have been. (Some problems would probably have developed no matter what).

A joint city state task force recommendation for an autonomous regional agency would have meant it was supported from the beginning by both the city and the state.With the sincere support of both sided things would have gone quicker after the referendum. It is difficult to see how things could have progressed much slower.

Other investigators* have noticed the tendency of the system to swallow new programs whole. What happened in other times and pla ces happened in Providence, Rhode Island in the 1980s. All attempts to evade the system fail for

* Pressman and Wildavsky; Derthick 
(short of revolution) the system remains and must be dealt with.

This makes a typical claim that is heard when a program is disappointing, that it would work if we could avoid "politics as usual" rather hollow. The roof would never leak if it didn't rain. But rain it does, and the roof will leak if it's not tended to. "Politics as usual" is the roof that must be patched, the fences that must be mended. A state agency that cannot function in the normal political hurly burly (which every society from Providence to Peking has) shouldn't have been set up in the first place.

Over the last year and a half the Bay Commission has had to cope with normalcy. When it was created at abruptly set down in the political landcscape, some long time institutional arrangements were disturbed; new rules had to be established.

These things to not seem important to the casual observer. To the people involved they are vital. It can seem trivial and petty to the outsider- the same way families losing their homes to a new highway seemed unimportant to people who lived a safe distance away.

To be critical when unhappy bureaucrats delay programs is a valid argument. To refuse to allow for such problems is self deception. It's not good politics, planning or administration.

In the normal course of events changes in bureaucratic 
regime take place at a slower pace and always out of the public eye. The new agency finds its niche in private, with none of the pain and jostling visible. What's out of sight might as well be invisible as far as the general public is concerned.

Things moved slowly in Providence for two reasons. First, things always move slow, short of war. The routine civili-' an agency work just doesn't (and can't) get the undivided attention of the politicians who could prod it to action. (if they dropped everything else) Nothing is more routine and politically unrewarding than sewage treatment. No one is going to get much credit, even if a great job is done. The other reason things went slow is because the Bay Commission was set up so fast. The city could be ignored in the planning stage, but it could not be avoided in the implementation phase. Instead of winning the city officials over in the task force phase they (the officials) felt insulted and ignored. An enemy was made, uselessly. If the players of the game looked at the events of 1979 honestly including Cianci's harshest critics) would they really be surprised at how things turned out? The wonder is that a transfer was worked out at all.

\section{$\mathrm{V}$}

The Mayor for his part deserves his fair share of the 
(107)

blame. It was reasonable, to a point, for Cianci to proteat his political position. Politicians live to win the next election; Vicnet Cianci is no exception. :

A point was reached where the Mayor appeared to procede from self interest to shabby exploitation. It is plain the Mayor was playing, as Trudy Cove complained " some kind of "political game". He abandoned whatever strutegy he was following only when it became apparent it was best for him to get rid of the plant. J lust what he thought he would accomplish only he and his inner circle know. If there was a legitimate public consideration the public should have been informed. If not they should know that, too. 
Inconclusive Conclusions

Now that the Bay Commission has asaumed control of the Providence sewage treatment system it can start being evaluated in terms of its mandate: to clean the Bay's waters. Will it get the job done? Will there be a significant reduction of the pollution of the Bay's waters? If the Commission does well its inauspicious beginnings will be forgotten. If not the whole idea will be seen as star crossed from the beginning.

Nobody, of course, has any idea what the Bay Commission will ultimately accomplish. That knowledge lies years in the future. No. one promises great things, at least not in public. Ronald Glantz and Robert Chase are both very negative toward the Commission. Glantz said, "It's the biggest joke...it'll never work."

Chase, upon hearing this remark agreed. "He's right." Are they right? It depends upon what you believe the public believes about what they were promised in 1980. Ronald Glantz thinks the public was promised clean water for its $\$ 87.7$ million. "Ask anybody out on the street what they voted for and that's what they'll tell you," Glantz said. In his view the referendum was an expensive deception.

There is no way to know what the people think without a survey. Some people undoubtedly believe that's what they voted for. But no one pushing the Bay Commission promised clean water. They promised cleaner water. Or, in the caut- 
ious words of Gary Sasse, " The degradation will be halted." ${ }^{1}$ In other words, things won't get any worse and will probably get better.

Speaking less rhetorically, Glantz saw the benefits of the project as toosmall the justify the scale of reconstruction and the amount of money to be spent on it. He attacked the regional commission and the sewer bonds as a project designed to benefit a very small number of shellfishermen and a larger (but still small) number of recreational boaters. Glantz pointed out it was events like the pollution of the Edgewood Yacht Club which ignited the first explosions which finally forced the Governor to act. Glantz made it clear he thought few Rhode Islanders cared much about the increased recreational opportunities they could not use without a boat. ( The day trippers will still do most of their salt water bathing in the lower Bay)

Oddly enough, the state's best known advoctate for the Bay, Trudy Coxe, agreed with a lot of what Glantz had to say about the events that got the Bay Commission rolling. She mentioned the Edgewood Yacht Club incident as a major impetus to action. "It got people together...", she said.

They parted company in matters of interpretation. Where Glantz tried to give the whole thing an elitist cast, Miss Coxe portrayed the Bay Commission supporters in 1980 as very public spirited. In the process she inadvertently helped make one of Glantz' points. 
She stated, in making the point her organization(with its "ten thousand members", was responsive to public sentiment, "We talk to people, we go to the boat shows." 2

This was said without a trace of irony on Trudy coxe' part. Are the people who go to boat the shows "the people" who matter in her eyes. We don't know. If Asked Trudy Coxe would surely deny it. But the questions remain: Who is this for ? Who really benefits ? Who really pays?

Ronald Glantz is prone to rhetoric and invective to excess. As a result his more perceptive comments tend to de overshadowed by his outrageous ones. He raised the issue of elitism. This program is undoubtedly the brainchild of an affluent elite, so there is more than a kernel of truth to his charges. How much more?

In The Environmental Protection Hustle Freiden pointed out a tendency by environmental groups to impose rules that fall disproportionately on others. In the case of California, Freiden concentrated on the increased housing costs which were causes at least in part by the no growth or slow growth policies imposed by California towns.

Providence is a different situation. Here a state bond issue was carried by referendum. All apparently pay to benefit from an improvement in the upper Bay's waters. What could be more fair? 
But the fact is the people of the new treatment district pay twice, first through their state taxes and second, through their user fees. The Bay Commission will pay off 16 of the $\$ 87.7$ million, plus $\$ 11$ million of old debt already held by the city of Providence. In the future there will be new bond issues as the system demands new capital. For the rate payers this could get very expensive. Yet they will have no choice but to pay the money necessary to operate and maintain the system.

Its very well for the boat owner in South county or the shell fishermen to claim they help retire the state bond issue. Their share comes to pennies. The people in the treatment district are paying directly, in significant amounts. ( $\$ 55$ a year per water meter or unit to start)

III

This is not an argument to forget the whole idea. Something had to be done about Field's Point. Any solution would have cost the public, even doing nothing. The interim repair job is only, as Ezra Schneider said, "A bandaid." The question becomes: What is necessary to insure a system which keeps the pollution situation at an acceptable point and will consistently work? This is a question which gets asked, but not answered. Anna Louise Nestman and John Kellam have asked it. Trudy coxe has suggested on several occássions that more studies be done of the total Bay pollution picture. Everybody admits were are woefully ignorant about just 
what exactly is being dumped into the Bay.

Without this data the question this paper has raised cannot be answered. In effect, the Anderson- Nichols facility plan of 1979 is being implemented even though it may be either a case of overkill or not relevant to the real problems.*

It is ironic that so much money has been set aside to build a system and almost no money has been set aside to evaluate technological needs. This may mean a "Cadillac" of a system gets delivered to a system which would prefer something more modest.

Ultimately anyone who cares about protecting the environment of this corner of the world can only shake their head and hope things turn out for the best. The way that has been chosen is the way that will be followed. Only a prophet could tell us the future; not to many od them are likely to be seen around City Hall or the state House anytime soon.

One conclusion can be drawn from all of this, though: When the political world calls for a quick solution, the solution tends to be bought "off the rack". If it fits, fine; if not you either stay with an ill fitting purchase or take it back for possibly expensive alterations.

* The 1979 Anderson-Nichols plan is not held in high regard in some circles. Staff at C.E. Maguire claim some of the plan's data is just plain wrong. 
References

Derthick, Martha: New Towns in Town; Why a Federal Program

Failed, Urban Institute, 1972

Frieden, Bernard J.: The Environmental Protection Hustle,

Cambridge, MIT Press, 1979

Pressman, Jeffrey and Wildavsky, Aaron: Implementation,

Berkely: University of California Press, 1979 
Appendix one: The State, the Management District and the Conditions of the States waters

Source: Rhode Island Statewide Planning program

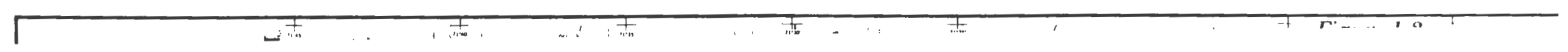


State Coastal Waters.

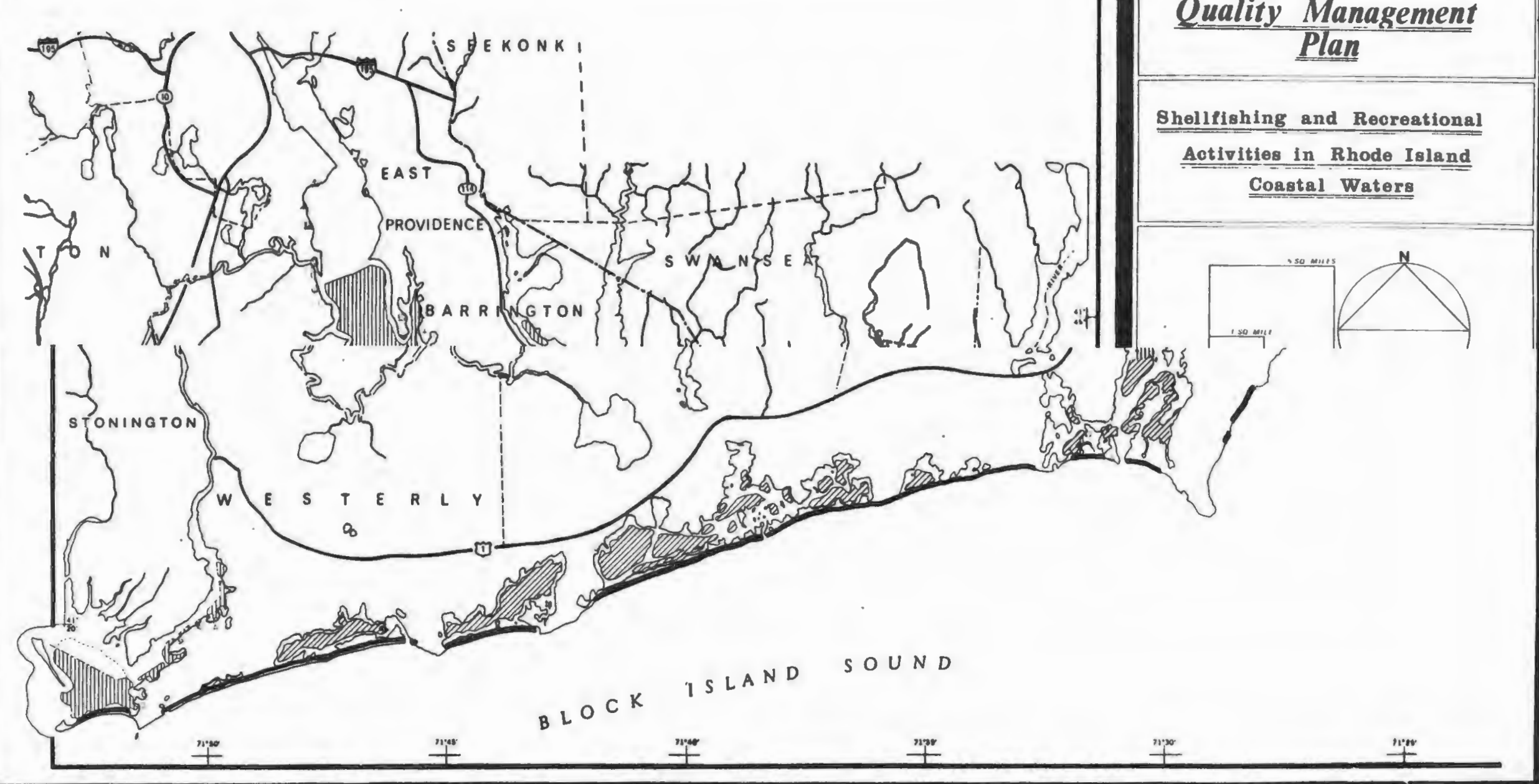



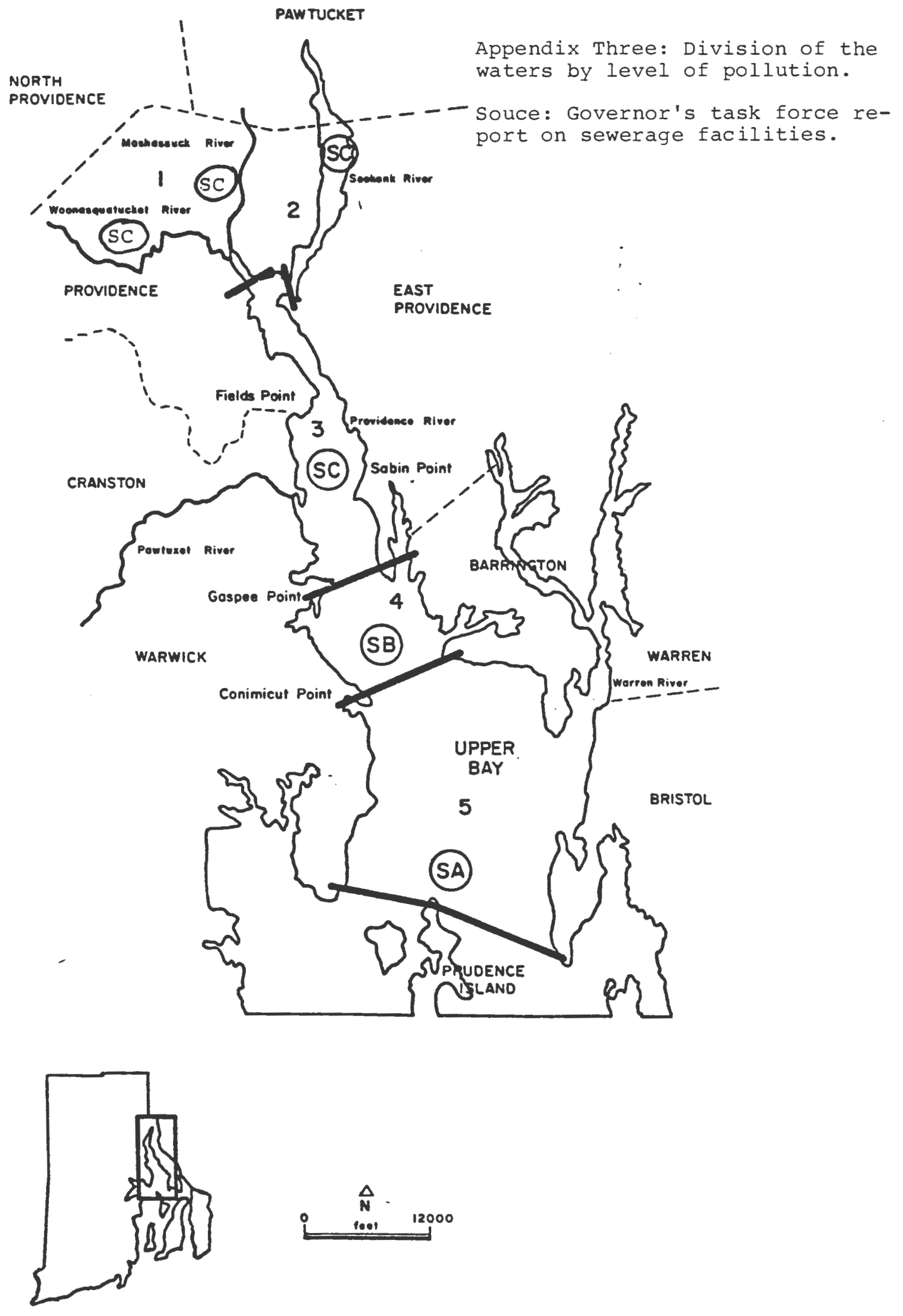
Footnotes

Chapter One: A Brief Description of the Bay

1. Chapter 342 P.L. 1980, p. 1373

2 . - Narragansett Bay: An Interpret-

ive Atlas : University of Rhode Island 1980 p. 4

3. Ibid, p. 6

$4-\div \quad$ Ibid

5. Ibid

6. Ibid pp. 8-12

7. Ibid

8. Ibid

9. Ibid

10. Ibid pp. $14 \pm-15$

11. Ibid p. 20

12 . - Water Quality Management Plan

for Rhode Island: Certification and Approval of Plan

Providence: Rhode Island Statewide Planning Program, 1980

p. 17

Chapter Two; Growth of Providence

1. Bacon, Edgar Mayhew. Narragansett Bay; Its Historic and Romantic Associations and Picturesque Setting, New York: G.P. Putnam's Sons, 1904 p. 20

2 . , Downtown Providence, Providence:

Rhode Island Historic Preservation Commission 1981. p.4.

3. McLoughlin, William G. Rhode Island: A Bicentennial History New York: W.W. Norton Co. 1978 p.124 
4. Ibid pp. 124-127

5. Ibid

6. Ibid

7. Snow, Edwin, M.D. Report of the superintendent of Health upon the Water of the Mosshassuck River. Providence 1877, pp. $4-5$

8. Snow, Edwin, M.D. Ist Annual Report of the Superintendent of Health in the City of Providence. Providence: Knowles Anthony and co. 1857 pp. 44-45

9. Ibid

10, Ibid

11. Mcloughlin, p. 124

12. Snow, Edwin,M.D. History of Asiatic Cholera in Providence Providence Journal, December 31,1857

13. Grey, Smauel. Proposed Plan for a Sewerage system. Providence: Providence Press Co. 1884 pp. $x-x i$

14. Ibid, p. ix

15. Ibid

16. , Providence City Manual

for 1902 "Inaugural Address of Daniel L.D. Granger, January 6, 1902" Providence: Snow, Farnum 1902 , p.21

Chapter Three: Events to the Mid Seventies

1. Providence Journal , February 27, 1914 , p.5

2. Ibid, February 26, 1919

3. , Report of the Metropolitan

Sewage Commission. Providence: December 13, 1933. P.1 
4. Ibid

5. Ibid

6. Ibid, p.2

7. Ibid pp. 18-19

8. Ibid

9. Ibid

10. John Kellam, Providence City Planning Department, Personal interview October 10, 1981. Mr. Kellam has a wide ranging jnowledge of city affairs since WW II.

11. Ibid

12. Ibid

13. Ibid

14. Ibid

15. Ibid

Chapter Four: A Brief Digression into the Political Environment

1. McLoughlin, p. 103

2. Ibid

3. Ibid, p. 104

4. Ibid

5. Ibid

6. Ibid

7. Ibid, p. 114

8. Ibid

9. Conley, Patrick T. The Dorr Rebellion; Rhode Island's Crisis in Constitutional Government. Providence: Rhode Island Bicentennial Foundation, 1976 pp. 1-3 
10. Ibid, p.I

11. Ibid, pp. 3-4

12. Ibid pp.5-6

13. Ibid, p. 7

14 Ibid, pp. 9-12

15. Ibid,

16. Haupt, Kenneth. Democratic Party Politics in Rhode Island 1883-1894. Unpublished History Senior Seminar Paper Rhode Island College, 1976 pp. 11-12.

17. McLoughlin, pp. 155-158

18. Ibid

18a.Ibid, p. 163

19. Levine, Edwin L. Theodore Francis Green. Providence: Brown University Press, 1971

20. McLoughlin, pp. 200-202

21. Providence Journal, January 2, 1935, p. 1

22. Ibid

23. The Journal-Bulletin Almanack, Providence: Providence Journal Co. 1959

Chapter Five: The Machine Stops

1. John Kellam

2. Ezra Schneider, Charles J. Krasnoff and Associates

3. John Kellam

4. - Water Quality Management Plan

for Rhode Island; Executive Summary. Providence: Rhode Island Statewide Planning Program, 1980 p. xvii 
5. Providence Journal, March 8, 1977, p. BI

6. Ibid, Narch 9, 1977, P.BI

7. Ibid, June 29, 1977

8. Ibid

Chapter Six: The Crisis I.

1. Ezra Schneider

2. Ibid

3. Providence Journal, July 30,1979 , P. A3

4. Ezra Schneider

5. Providence Journal, June 27, 1979 P. B4

6. Ibid, March 23, 1979, p. Cl4

7. Ibid

Chapter Seven: The Crisis II: The Dam Bursts

1. Providence Journal, July 26, 1979, p. A3

2. Ibid, P. A2

3. Ibid, August 1, 1979, p. Al

4. Ibid, p. A3

5. Ibid

6. Ibid, August 3, 1979, p. A3

7. Ronald Glantz, former Chief of Staff to Mayor Vincent Cianci, Personal interview, March 11, 1982

8. Providence Journal, August 8, 1979 , p. A3

9. Ibid

10. Ibid, August 9, 1979, p. Al 
11. Ibid

12. Ibid

13. Ibid, August 12. 1979. p. C4

14. Ibid, August 18, 1979, p.A5

15. Louise Durfee, Governor's task force Chair, Personal interview, January 27, 1982

16. Providence Journal, August 23, 1979 p. A3

17. Ibid

18. Ibid, August 30,1979, p. A3

19. Ibid, September 14, 1979, p. Cl

20. Ibid, september 19, 1979. P. Cl

21. Ibid, september 26, 1979. p. B4

22. Ibid, November 9, 1979, P. A3

23. Ibid, November 20, 1979, p. Al0

24. Ibid, November 24, 1979, p.A3

25. Ezra Schnieder.

Chapter Eight: Toward a Bay Commission I

1. Providence Journal, August 1, 1979, P. Al

2. Gary Sasse papers.

Chapter Nine: Toward a Bay Commission II

1. - Report of the Governors Sew erage Facilities Task Force. February 1980, p. 2

2. Ibid

3. Ezra Schneider 
4. Eva Hoffman, University of Rhode Island

5. Task Force, p.2

6. Eva Hoffman

7. Task Force, p. 5

8. Ibid, p.8

9. Ibid

10. Ibid

11. Ibid

12. Ibid, p. 9

13. Providence Journal, 1980. Undated clipping Gary Sasse papers.

14. Task Force, p. 10

15. Ibid

16. Ibid

17. Ibid

18. Ibid. p.II

19. Ibid

20. IBid

21. Ibid, pp.13-14

22. Ibis, pp.14-15

23. Ibid.

24. Ibid, p. 116

25. Ibid, pp.17-18

26. Ibid

27. Ibid

28. Gary Sasse, Governor's Task Force,personal interviee, February 26, 1982 
29. Provodence Journal. January 22, 1980, p. Al

30. Ibid, February 1, 1980, p. A3

Chapter Ten: The Grand Coalition

1. Louise Durfee

2. Rhode Island State Archives

3. Mary Kilmarx, Governor's Task Force, Personal interview February 26,1982

4. RI State Archives

5. Ibid

6. Mary Kilmarx

7. Providence Evening Bulletin, April 4, 1980, p. Bl; Ronald Glantz

8. Mary Kilmarx

9. Ronald Glantz

9a. Ibid

10. Mary Kilmarx

11. R.I. State Archives

12. Ibid

13. Ibid

14. Ibid

14a.Chapter 342 P.L.1980 pp. 1373-1374

15. Ibid, p. 1376

16. Ibid, p. 1377

17. Ibid, p. 1400

18. Ibid, pp.1380-1381

19. Ibid, p. 1385

20. Ibid, p. 1395 
22. Al Bagaglia, House Finance Committee Staff

23. Providence Journal, April 1980. Undated clipping Gary Sasse Papers.

24. Gary Sasse

25. Providence Journal, October 1, 1980, p. Bl4 26 . , Official Count of the Ballots

Cast at the Election, Tuesday, November 4, 1980. Providence: State Board of Elections, 198I, p.365

27. Ibid, p. 34

28. Ibid, p. 42

29. Ibid, p. 37

Chapter Eleven: Trouble Getting off the Ground

1. Providence Journal, February 1, 1981, P.Al

2. Ibid, January 21,1981, p.Al

3. Ibid, Janaury 23, 1981, p. Al

4. Ibid, January, 24, 1981, p. A1

5. Ibid

6. Ibid

7. Ibid, January 29, 1981

8. Ibid, January 23, 1981, P. Al4

9. Ibid, January 31,1981, p. Al

10. Ibid, January 22,1981, p. Al

11. Ibid, February 1, 1981, p. Cl1

12. Ibid, January 24, 1981, P. Al

13. House Finance Committee

14. Providence Journal, February 1981. Undated clipping personal coleection. 
15. Ibid

16. Ibid

Chapter twelve: On the Back Burner

1. Providence Journal , February 1981, Undated clipping personal collection

2. Robert Chase, Aide to Mayor Cianci, personal interview January 27,1982

3. Ibid

4. Eric Jankel, Executive Director, Bay Commission, personal interview January 27,1982

5. Robert Chase Papers

6. Eric Jankel

7. Ibid

8. Ibid

Chapter Thirteen: The Negotiations

1. Robert Chase

2, Eric Jankel

3. Ibid

4. Providence Journal, July 22, 1981

4a. Eric Jankel

5. Ibid

6. Draft Agreement, 6/28/81 Robert Chase Papers

7. Eric Jankel

8. Eric Jankel

9. Robert Chase Papers 
10 . , Acquisition Agreement By and

Between the City of Providence and the Narragansett Bay Water Quality Management District Commission, December 16, 1981 Press release summary, p. 2

11. Ibid

12. Ibid

13. Ibid, p. 3

14. Ibid

15. , Inge Co. v City of Providence, et al. C.A. 82-378. Clerk of the superior Court 16. Ibid

17. Ronald Glantz

18. Ezra Schneider

19. Providence Journal, December 18, 1980

20. Ibid

21. Inge Co. $\mathrm{V}$ Providence

22. Eric Jnakel

23. Acguisition Agreement, p. 29

25. Eric Jankel

25. Ibid

26. Trudy Coxe, Executive Director, Save the Bay, Personal interview, January 22, 1982

Chapter Fourteen: By and for Whom?

1. Ezra Schneider

2. Ibid

3. Ibid

3. Ibia 
4. Ibid

5. Ibid

6. Ibid

7. Ibid

8. Ibid

Chapter Fifteen: The Endgame

1. Providence Journal, March 17, 1982, p. A1

Chapter Seventeen: Inconclusive Conclusions

1. Gary Sasse

2. Trudy Coxe, January 22, 1982 